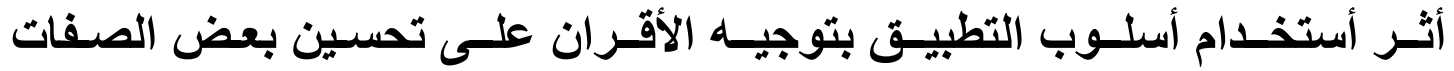

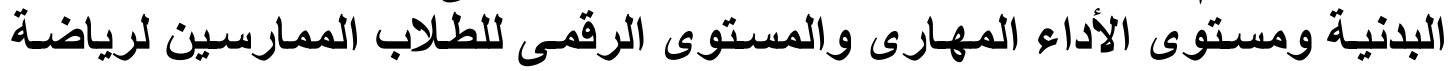

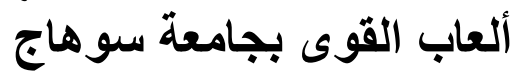

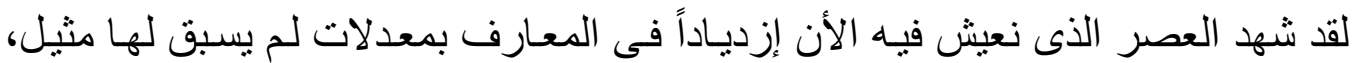

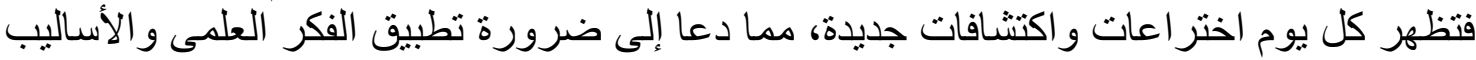

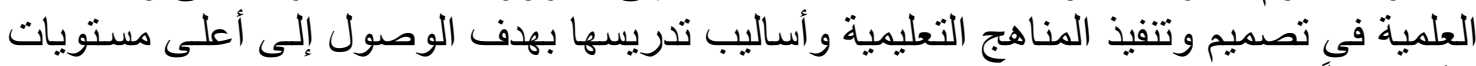
الأداء وفقاً لقدر ات المتعلمين وخصائصهم فى مختلف المستويات التعليمية.

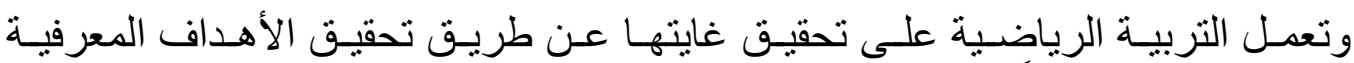

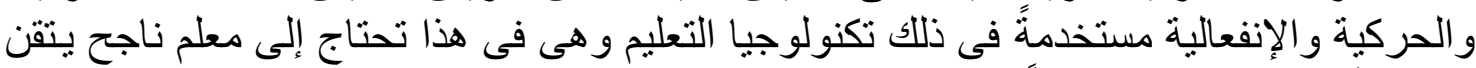

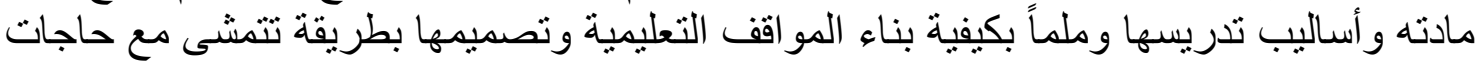

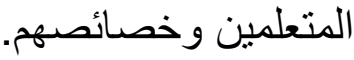

وتثنير " ميرفت خفاجة" ( (99 1) إلى أن أساليب التدريس التى يستخدمها المعلم تعتبر

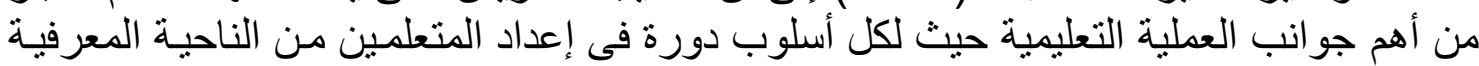

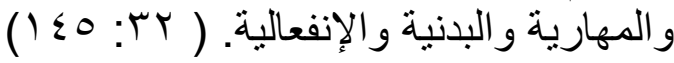

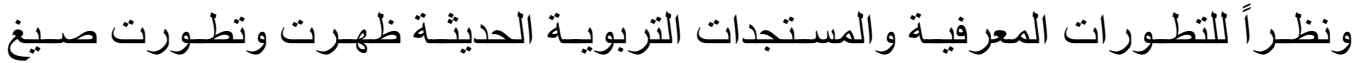

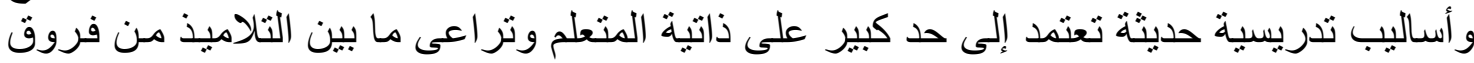

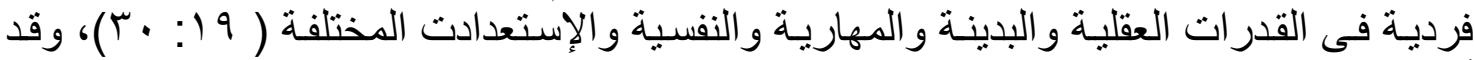

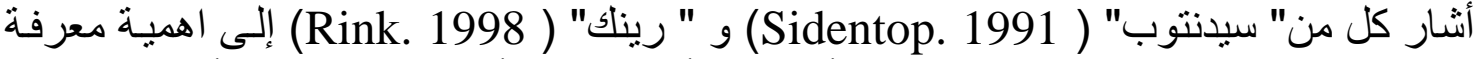

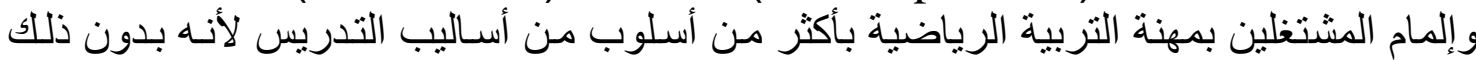

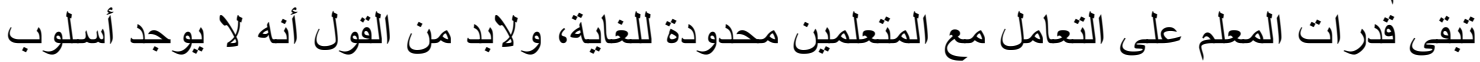

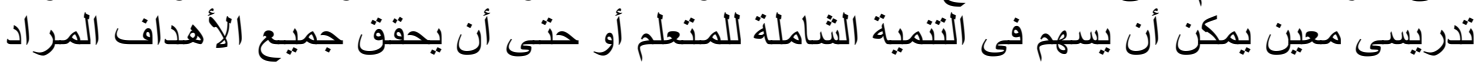

$(119: \leqslant \cdot)(0 \leqslant: \leqslant r)$

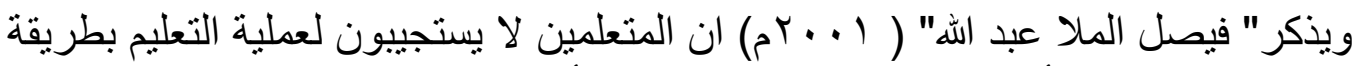

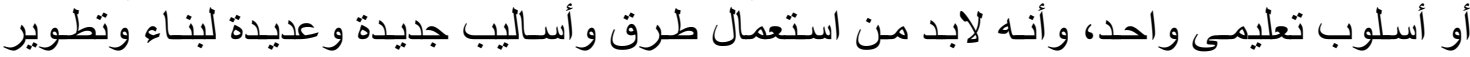

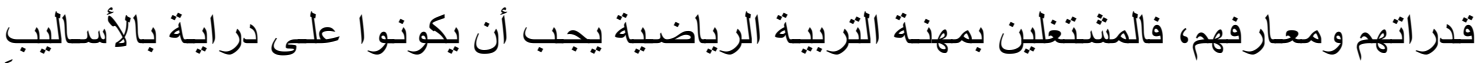

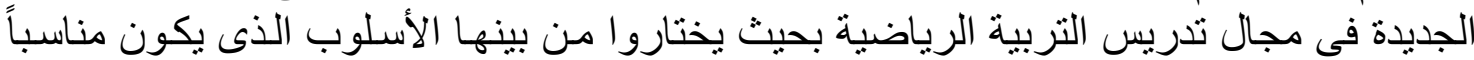

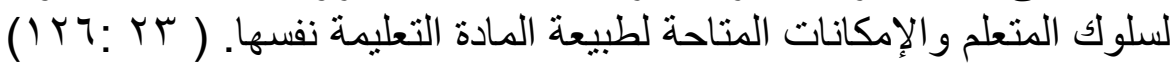

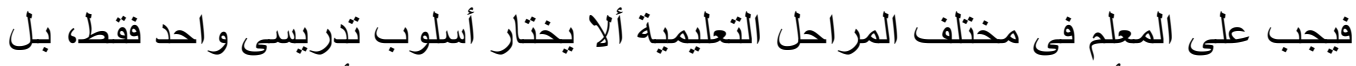

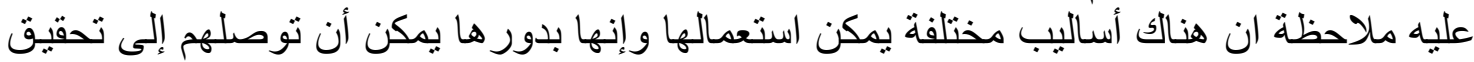

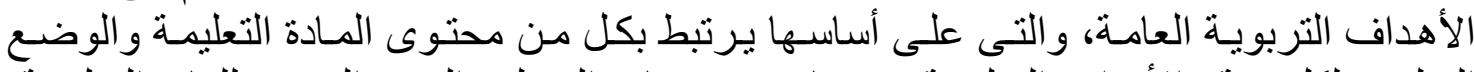
التعليمى لكل بيئة و الأهداف التعليمية وخصائص وصلية ولئات المتعلم و الزمن المنوفر للمادة التعليمية. 


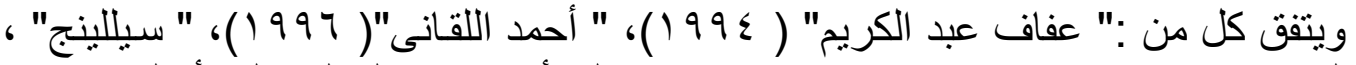

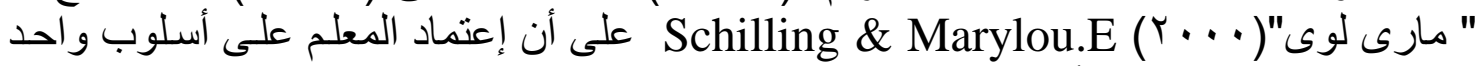

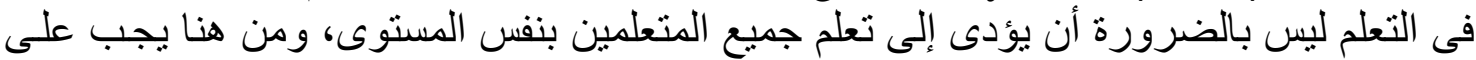

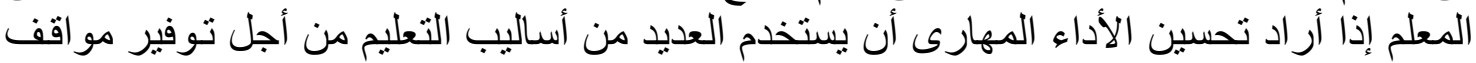

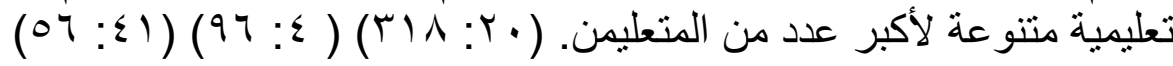

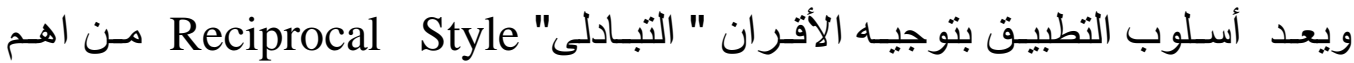

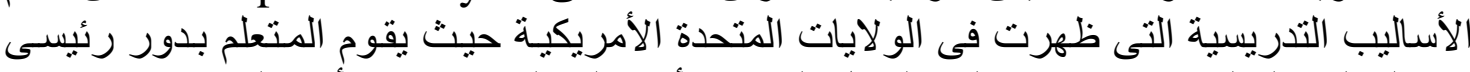

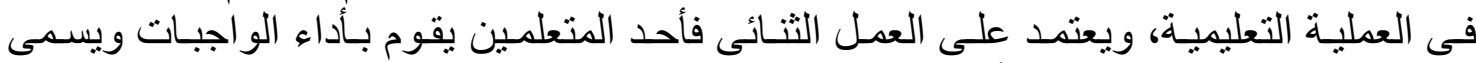

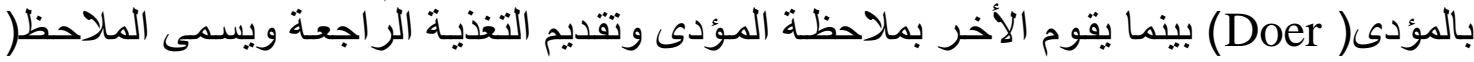
(Observer

$(1 r \cdot: r \mu)$

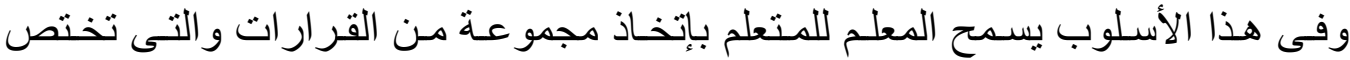

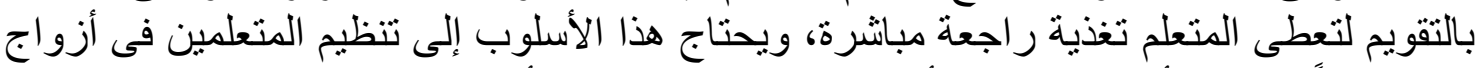

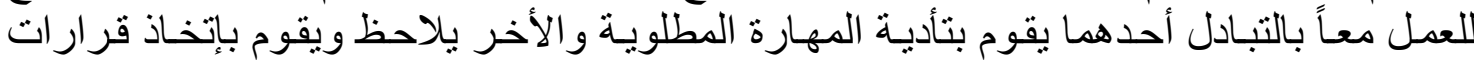

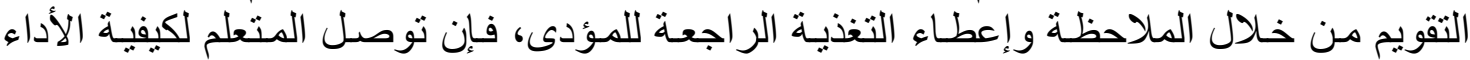

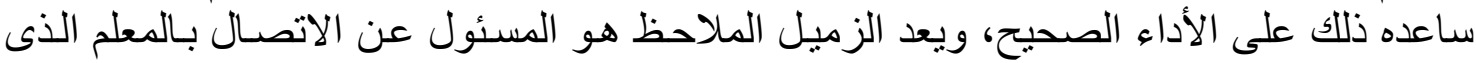

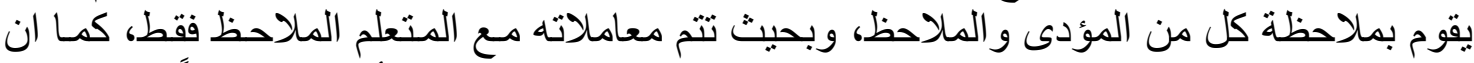

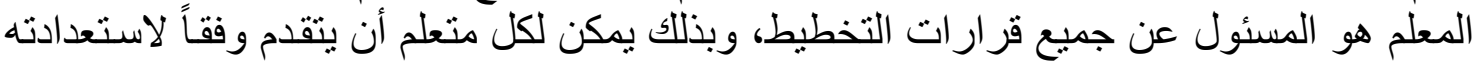

$(101: 44)(1 r \leq: 10)$

وقدر اته. - اته

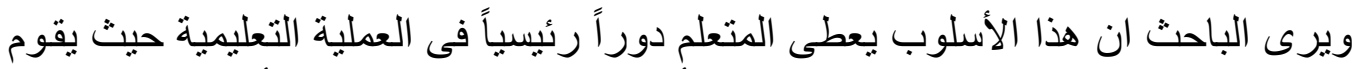

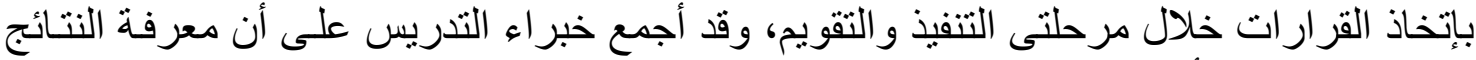

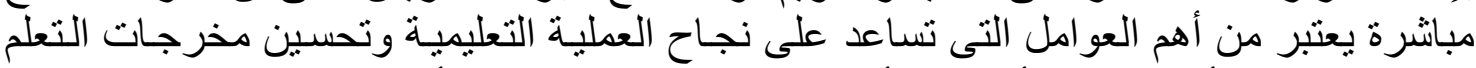

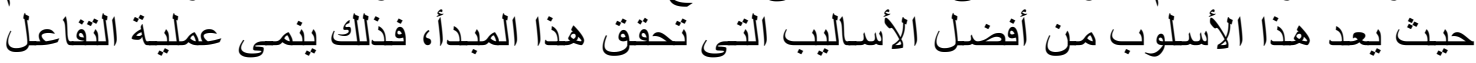
الإجتماعى بين التلاميذ من خلال الأداء أو العمل الثنائى بين الأقران.

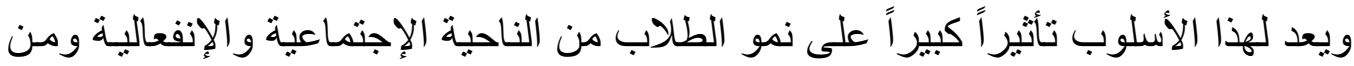

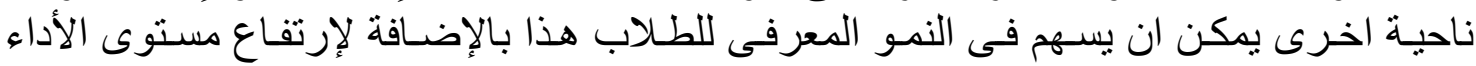

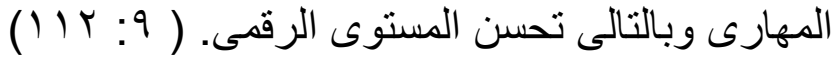

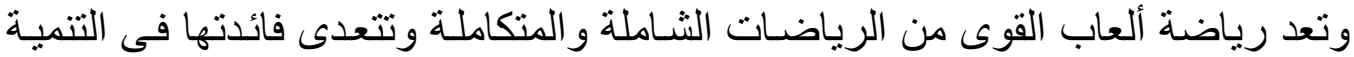

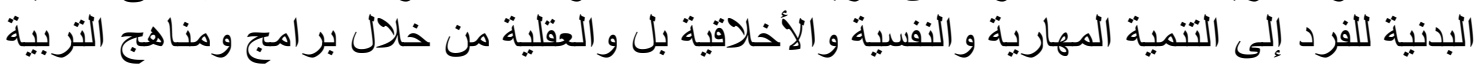

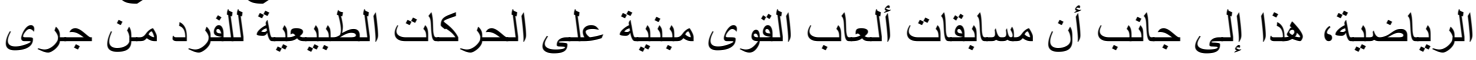

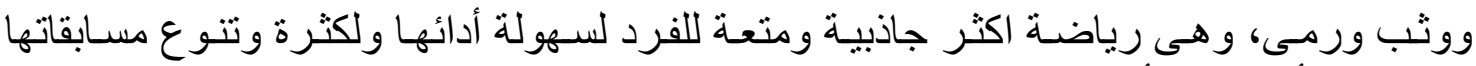

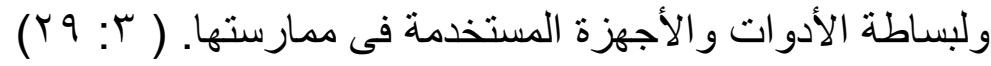

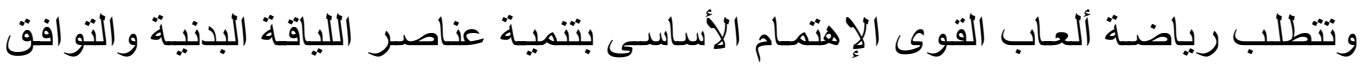

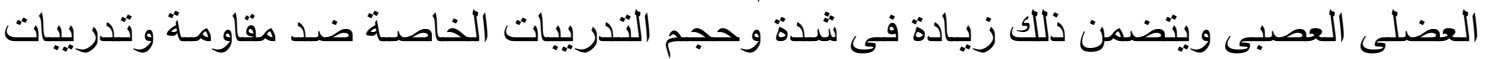


الأثقال المختلفة والكرات الطبية حيث يستطيع المتدريب أداء مهارة الرمى باليد مع تدريب اجزاء الإهاء

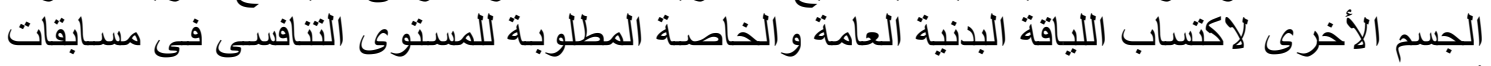

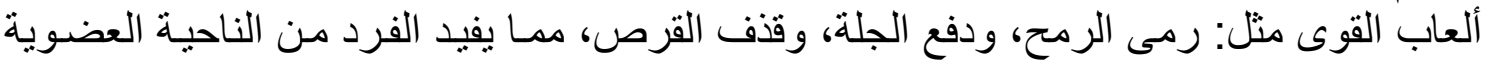

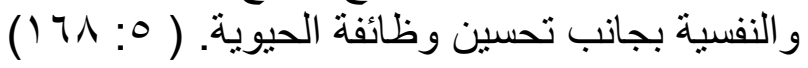

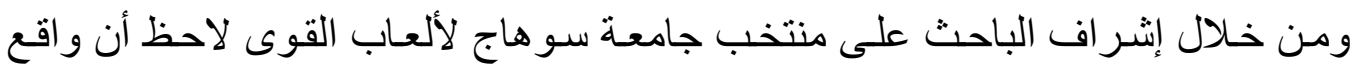

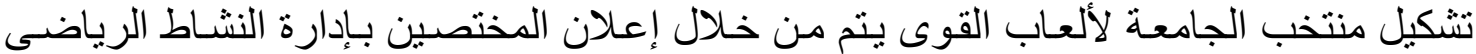

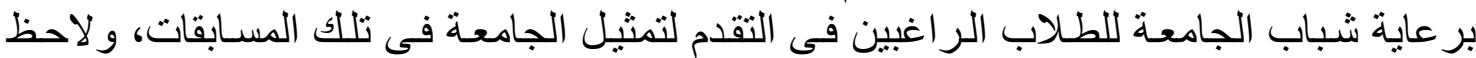

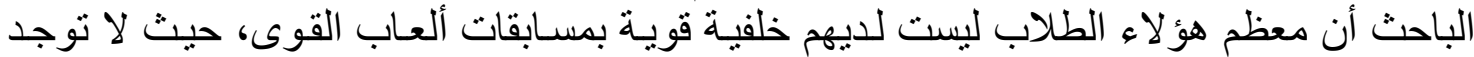

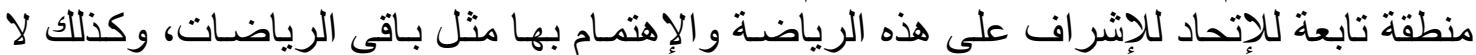

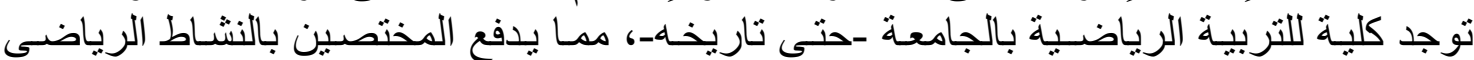

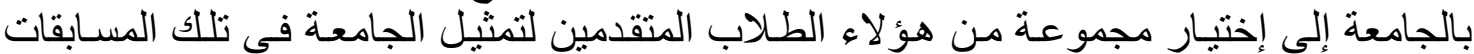

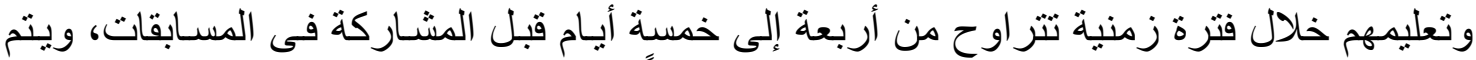

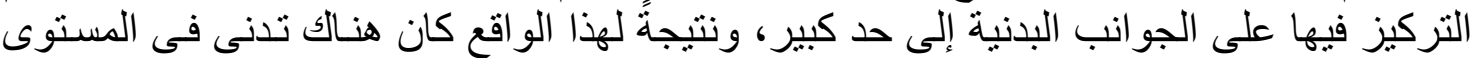

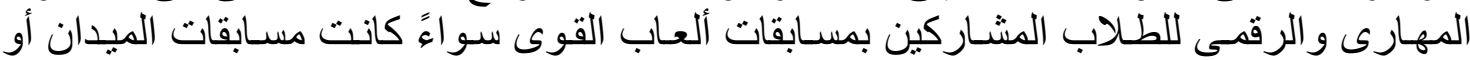
المضمار ، و هذا ما لاحظه الباحث.

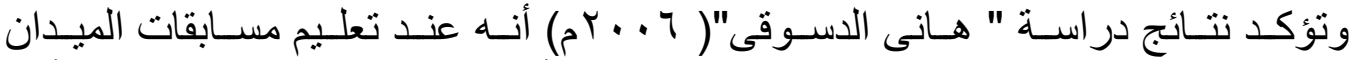

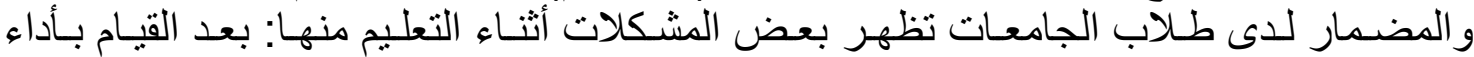

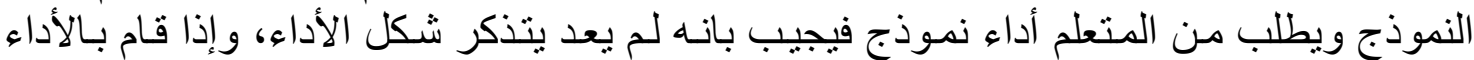

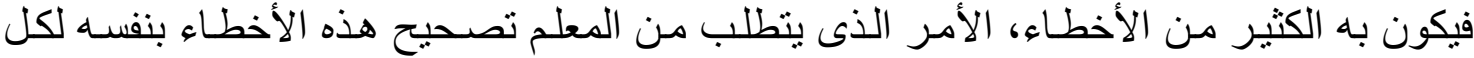

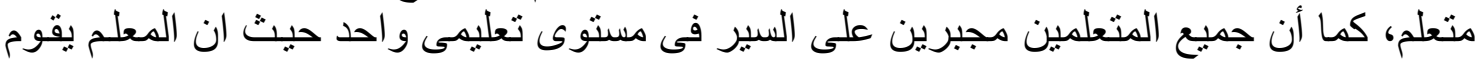

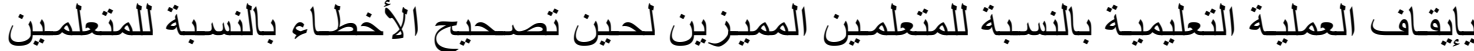

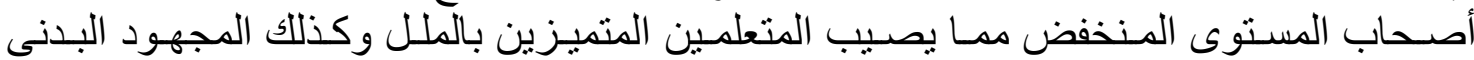

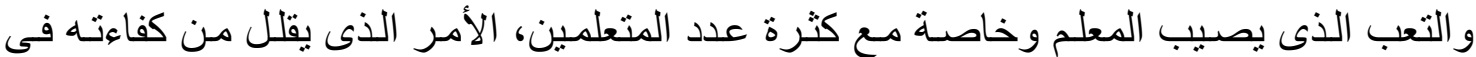

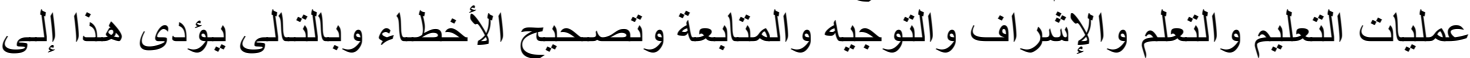

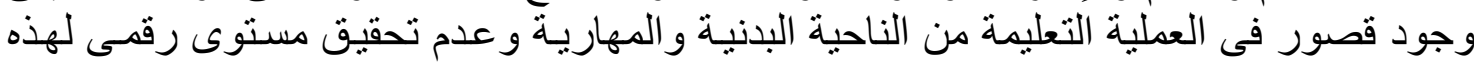

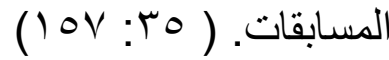

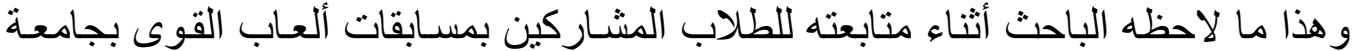

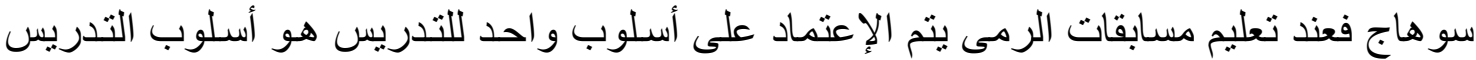

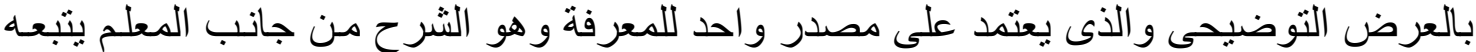

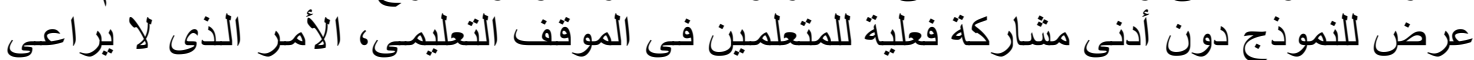

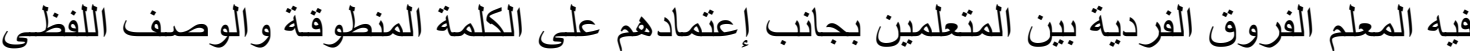

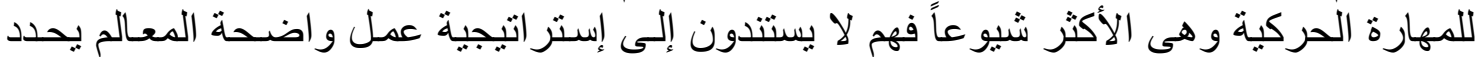

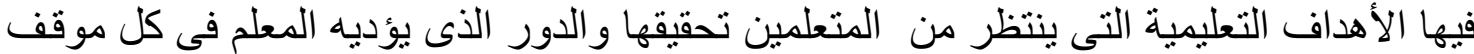

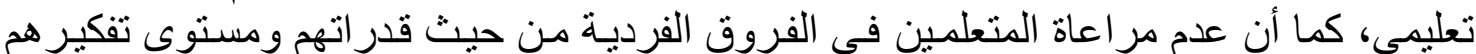

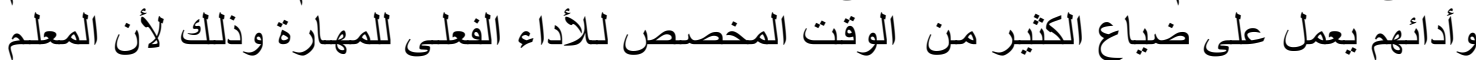

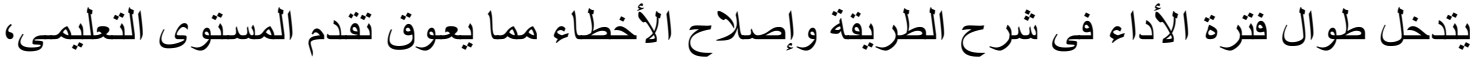

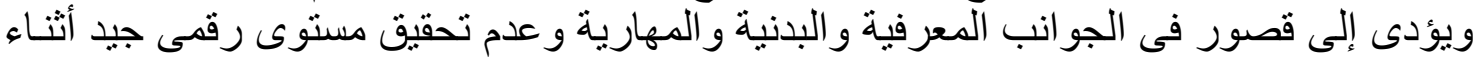

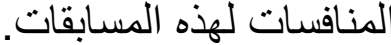


مما دعا الباحث إلى ضرورة التدريس باستخدام أسلوب التطبيق بتوجيه الأقر ان فى تعلم مسابقات

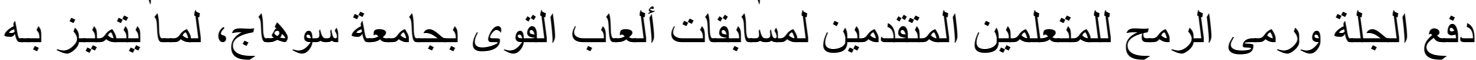

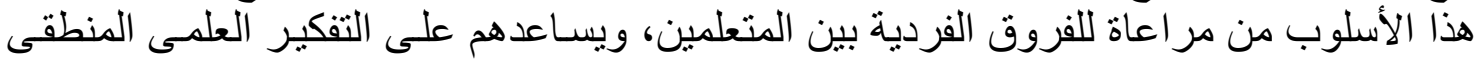

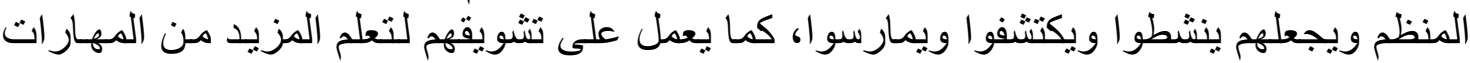

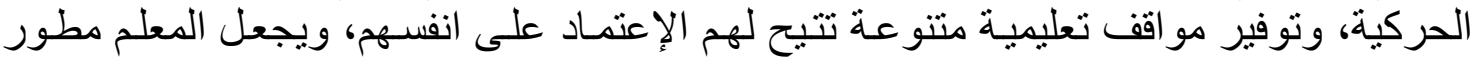

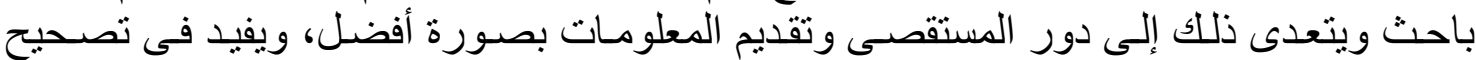
الأخطاء كما تر اعى هذه الأساليب مستوى ونضج وخبرة المتعلمين، ويساعدهم على التعاون فيمـا

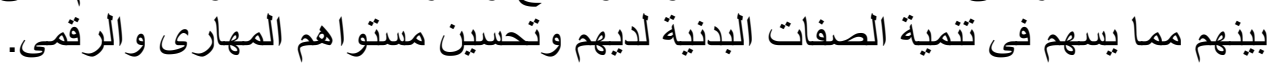

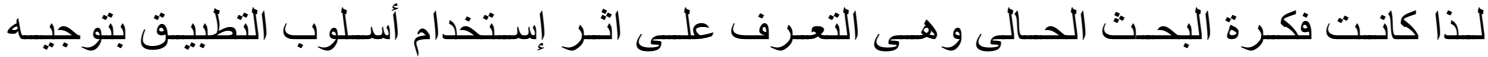

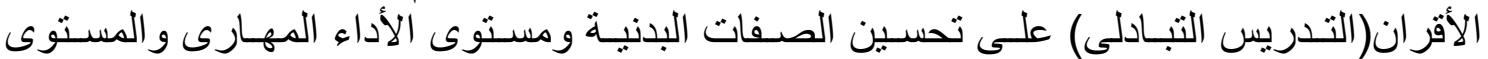
الرقمى لطلاب جامعة سو هاج المشاركين بمسابقات ألعاب القوى. لابن.

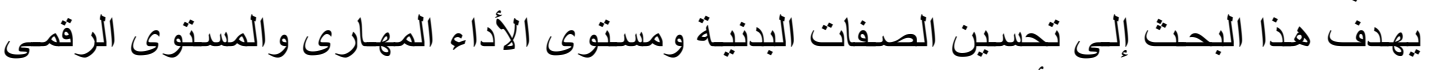
للطلاب الممارسين لرياضة ألعاب القوى بجامعة سو هاج.

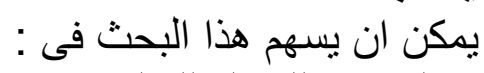

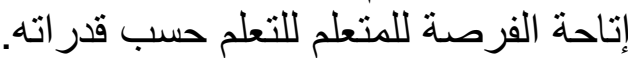

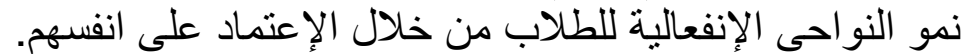

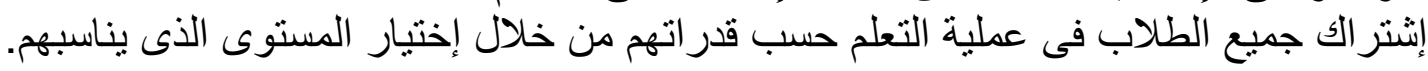

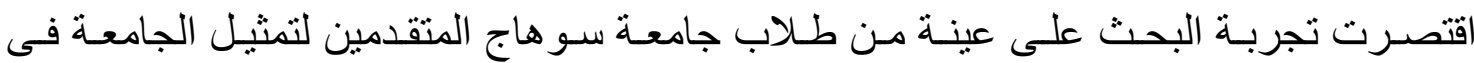

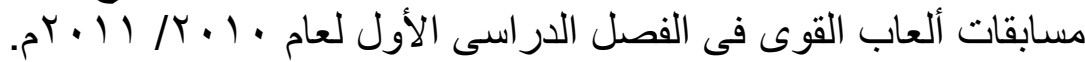

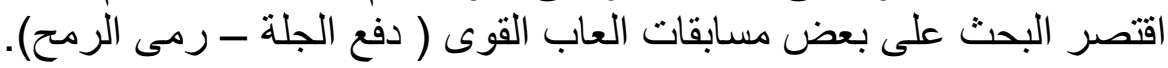

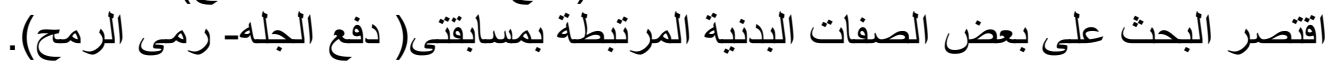

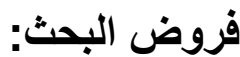 \\ يحاول البحث التحقق من صحة الفروض التح التالية:}

يوجد فرق ذو دلالة إحصائية بين متوسطى درجات أفر اد عينـة المجمو عـة التجريبية و المجموعة

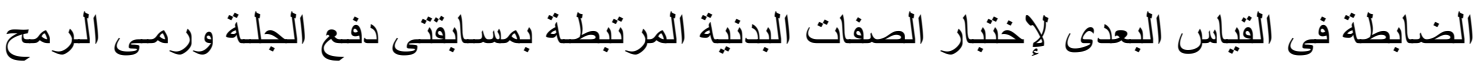
لصالح أفر اد عينة المجمو عة الفيلة التجريبية.

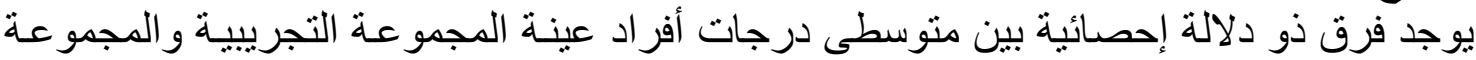

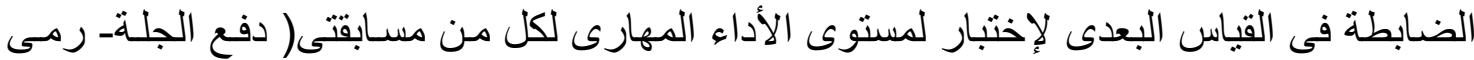

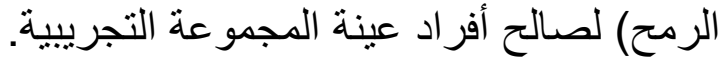

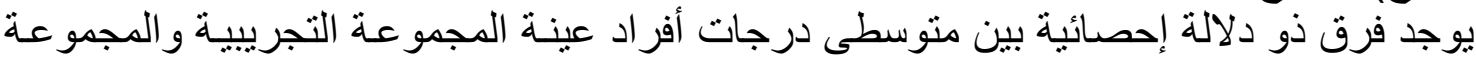

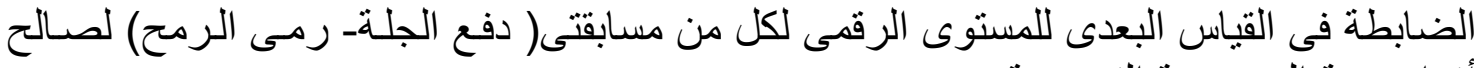
أفر اد عينة المجمو عة التجريبية. 
أسلوب التطبيق بتوجيه الأقران( التعلم التبادلى)

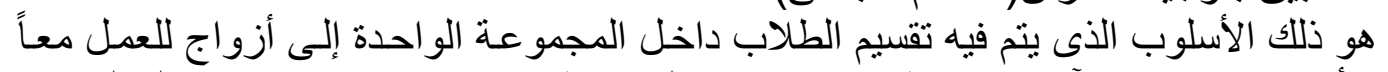

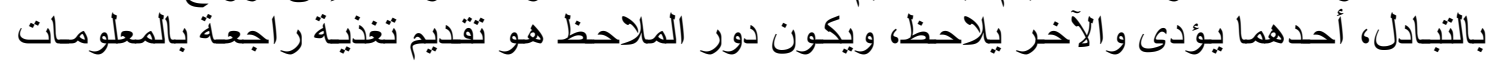

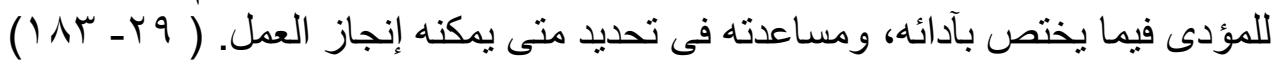

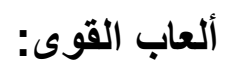

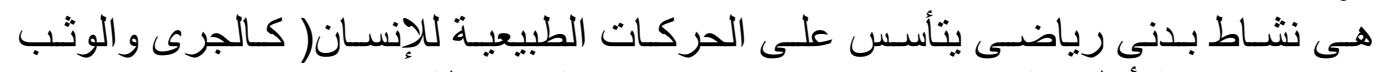

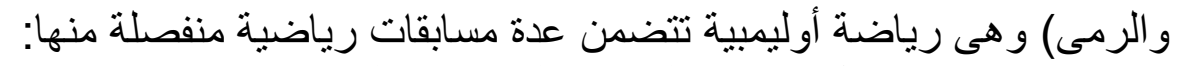

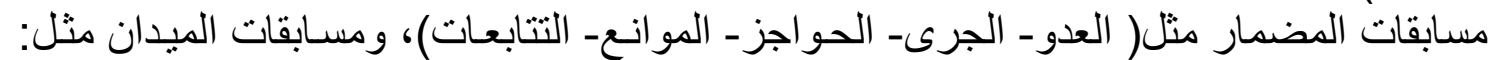

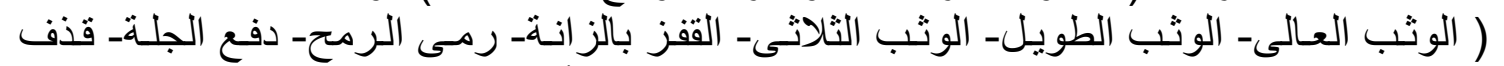

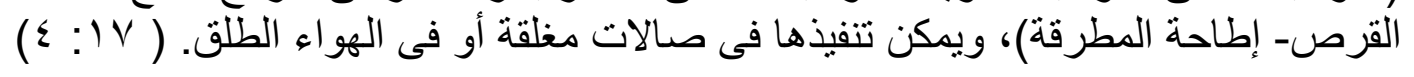

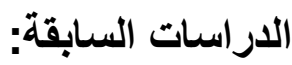

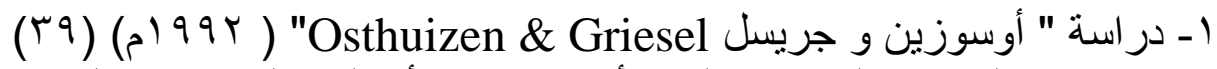

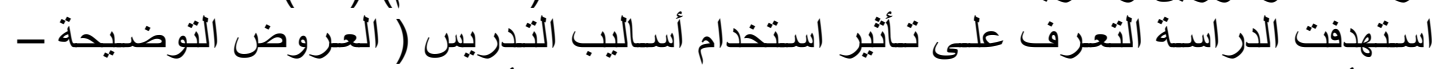

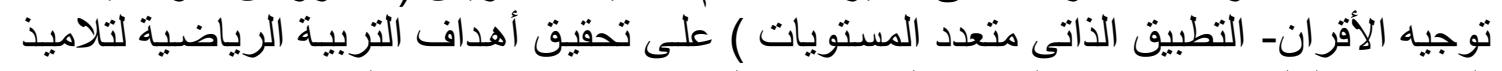

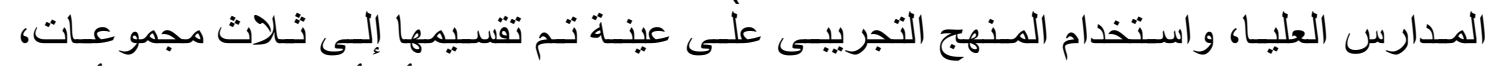

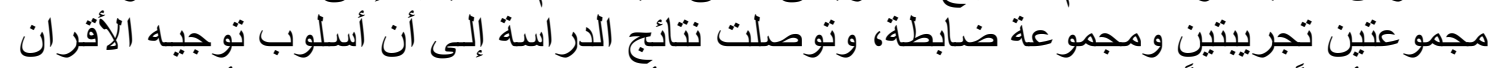

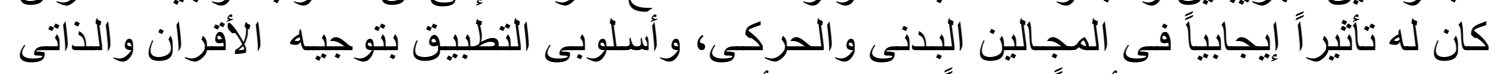

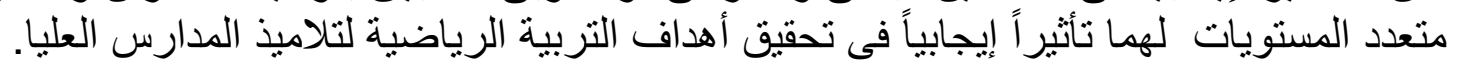

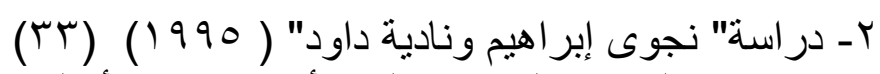

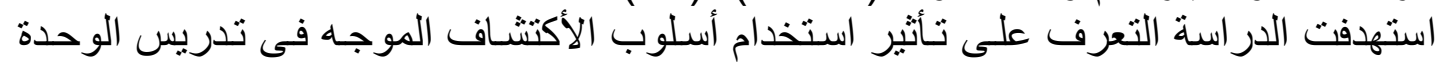

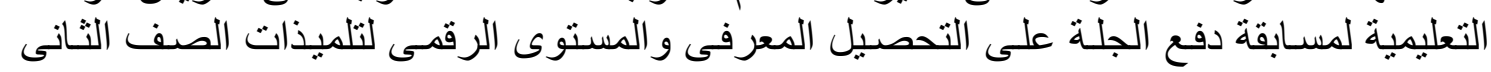

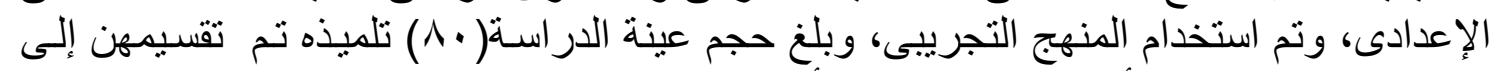

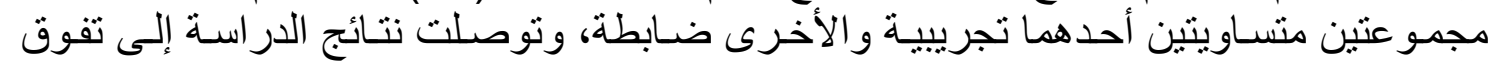

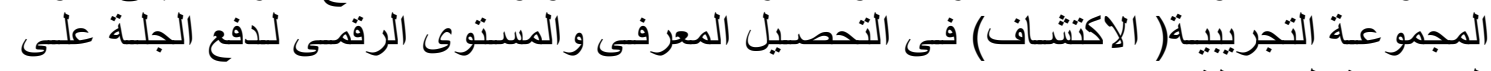

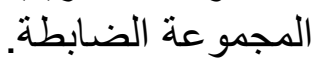

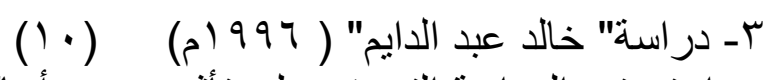

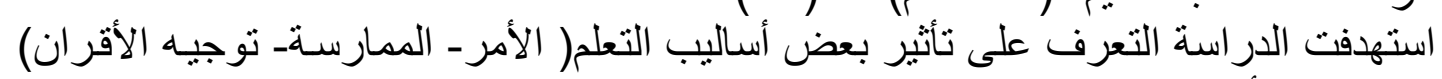

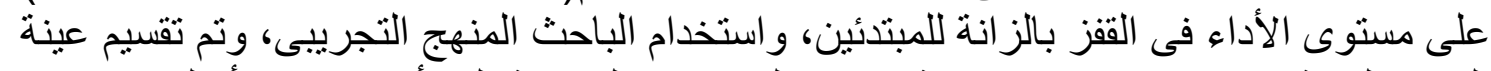

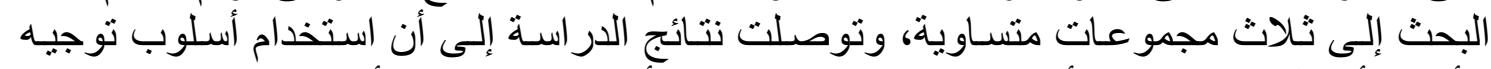
الأقران أفضل من استخدام أسلوب الممارسة والتعلم بالأمر فى مستوى الأداء للقفز بالزانة.

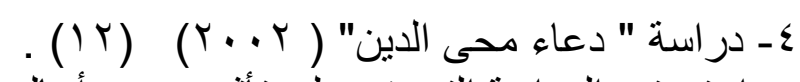

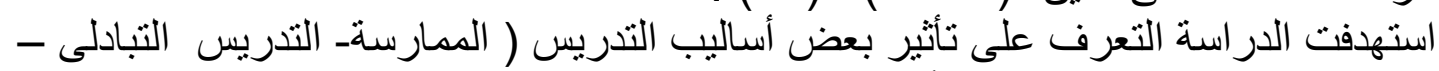

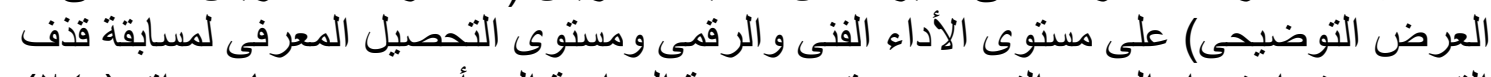

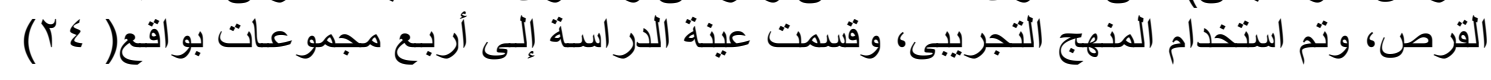


طالبة لكل مجموعة، وتوصلت نتائج الدراسـة إلى أن للأسـاليب الثلاثة تأثنير إيجابياً على تعلم مسابقة قذف القرص.

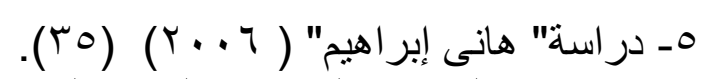

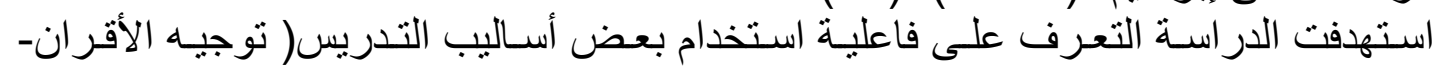

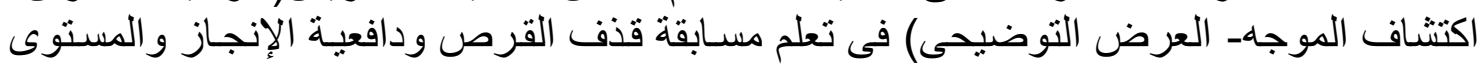

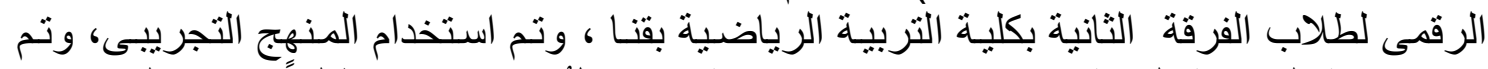

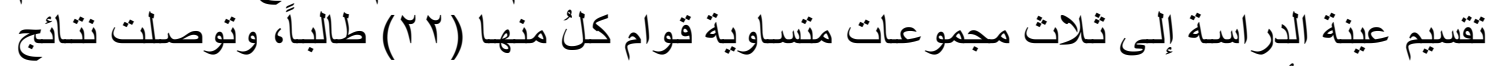

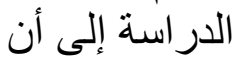
أ ـ أفضل الأسـاليب لتعلم مسـابقة قذف القرص هو أسلوف أسلوب التعلم بتوجيه الأقران يليه أسلوب

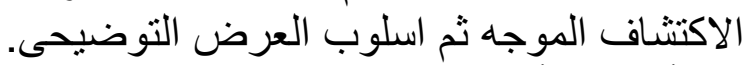

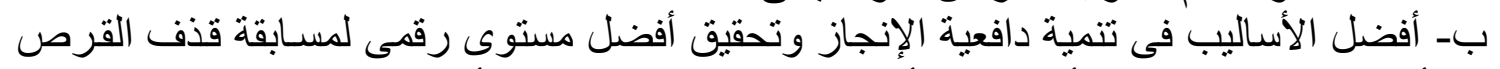

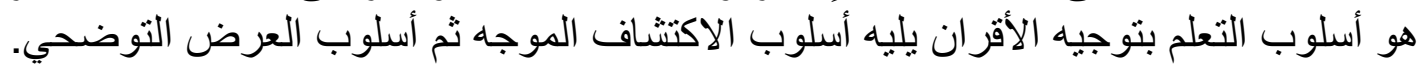

$$
\text { منهج البحث: البحث: }
$$

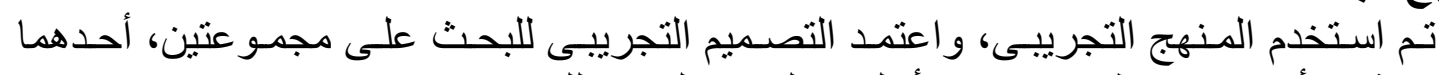

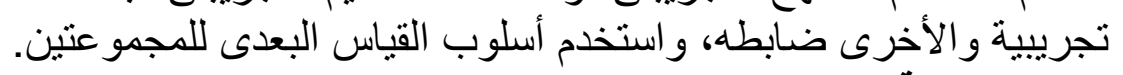

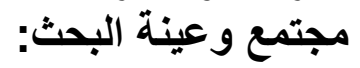

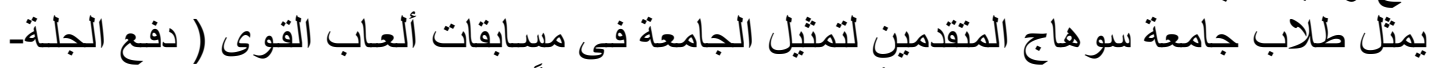

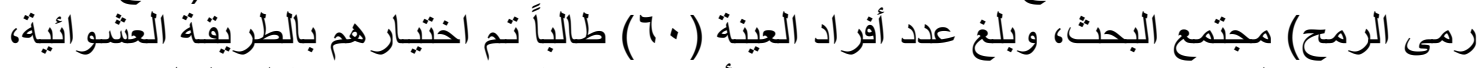

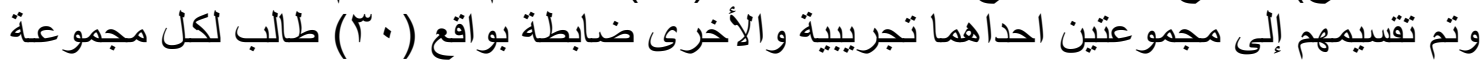

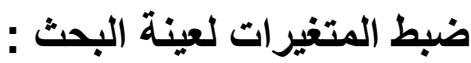

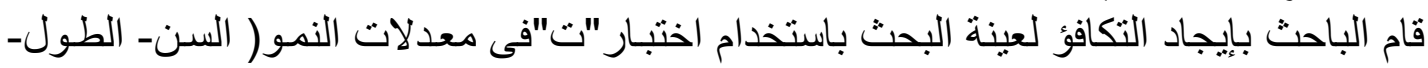

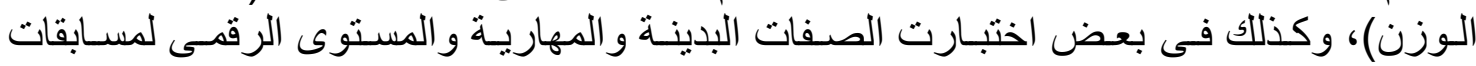

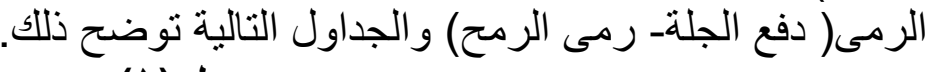

\section{جذول (1)}

\begin{tabular}{|c|c|c|c|c|c|c|c|c|}
\hline مستوى الدالة & \multicolumn{2}{|c|}{ ت } & \multicolumn{2}{|c|}{ المجموعة الضابطة } & \multicolumn{2}{|c|}{ المجموعة التجريبية } & \multirow{2}{*}{ والقياس } & \multirow{2}{*}{ المتغيرات } \\
\hline$\cdot, .0$ & الجدولية & المحسوبة & المعيارى & الحسابى & الإعبارى & الحستابى & & \\
\hline غير دال & \multirow{3}{*}{$1,7 \mathrm{~V}$} & $\cdot, 17$ & $\cdot, \wedge \theta$ & $r \cdot, r Y$ & $\cdot, 9$ & $r \cdot, M_{T}$ & سنة & السن \\
\hline غير دال & &., 10 & $\bullet, \wedge \wedge$ & $1,79 \leq$ & 0,99 & 1,794 & سم & الطول \\
\hline غير دال & & $\cdot, r V$ & $\Lambda, \vee \vee$ & $V_{Y Y, V T}$ & $\Lambda, \cdot \Lambda$ & $V_{r}, r q$ & كجم & الوزن \\
\hline
\end{tabular}

التوصيف الإحصائى لمجموعتى البحث فى متغيرات ( السن- الطول- الوزن)

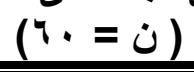

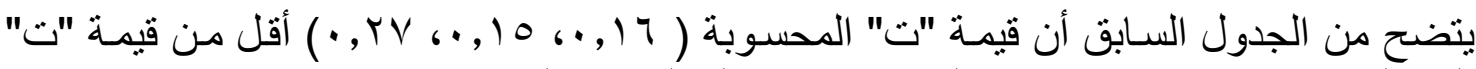

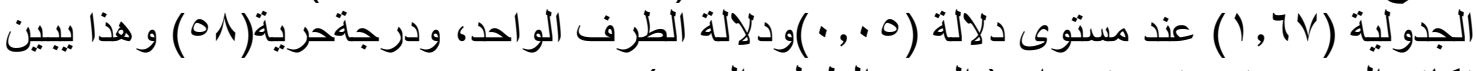
تكافؤ المجمو عتين فى متغير ات( السن، الطول، الوزن) 


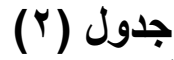

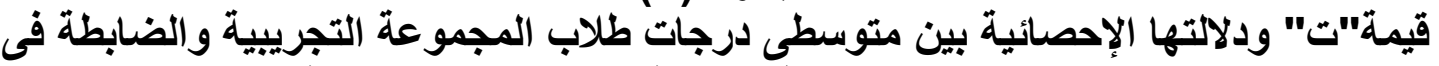

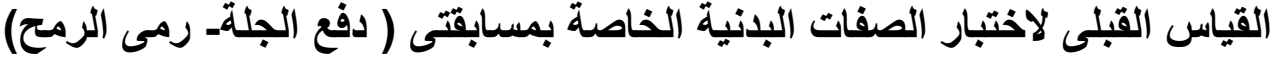

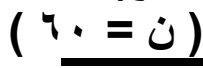

\begin{tabular}{|c|c|c|c|c|c|c|}
\hline \multirow{2}{*}{ "قيمـة "تمستة } & \multicolumn{2}{|c|}{ المجموعة الضابطة } & \multicolumn{2}{|c|}{ التجمبوعة التجية } & \multirow{2}{*}{ والقياســــ } & \multirow[t]{2}{*}{ الاختبارات } \\
\hline & $\varepsilon$ & 5 & $\varepsilon$ & r & & \\
\hline$\cdot, 1 \leq$ & $1, \cdot r$ & $11,1$. & $1, \cdot 4$ & 11,11 & متر & رمى كرة سلة \\
\hline$\cdot, \mathrm{\wedge}$ & $\cdot, 19$ & $1, \varepsilon r$ & $\cdot, I V$ & $1, \leqslant \varepsilon$ & 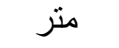 & الوثب العريض برجل الارتكاز \\
\hline$\cdot, 11$ & $r, Y_{1}$ & $r \cdot, r T$ & $r, 19$ & $r \cdot, 17$ & 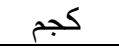 & قوة القبضة \\
\hline$\cdot$, ro & $1,7 \varepsilon$ & $4,1$. & $1,0$. & YI, . & كجم & قوة عضلات الظهر \\
\hline$\cdot, 00$ & 1,0 & $r \varepsilon, \cdot T$ & $1, Y \wedge$ & $r \varepsilon, Y T$ & سم & نيلسون للسرعة الحركية \\
\hline$\cdot, 0 \mathrm{~V}$ & 1,19 & $\mathrm{~V}, \mathrm{~V} \cdot$ & $\cdot, 9 \varepsilon$ & $v, 01$ & 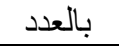 & اللمس السفلى الجانبى \\
\hline$\cdot, 01$ & $r, 00$ & $00, \cdot V$ & I, ו & $00, \Sigma$. & الثانية & الحبو \\
\hline$\cdot, 11$ & $1,+7$ & $\varepsilon, 1$. & $1, Y \cdot$ & $\varepsilon,+7$ & 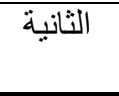 & 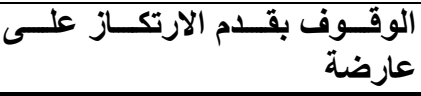 \\
\hline
\end{tabular}

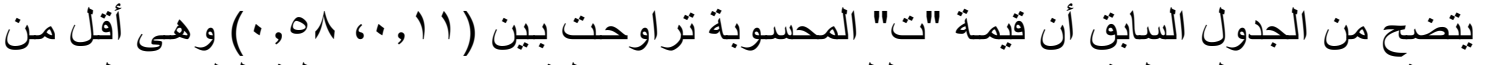

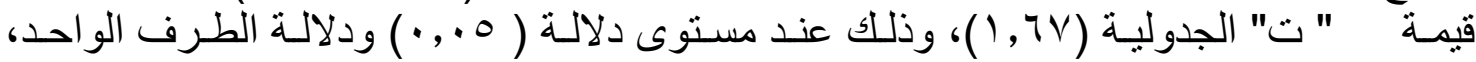
ودرجة حرية (01) ـ و هذا يبين تكافؤ المجمو عتين فى الصفات البدنية.

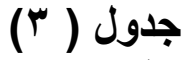

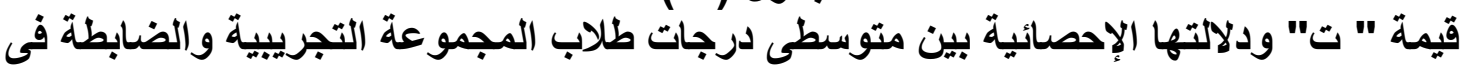

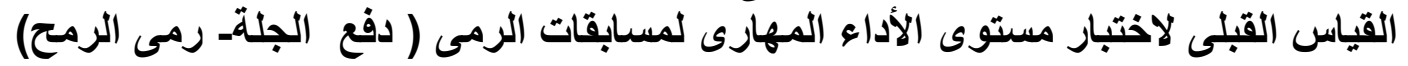
$1 \cdot=\dot{10}$

\begin{tabular}{|c|c|c|c|c|c|c|c|}
\hline \multirow{2}{*}{ "قيمة "تية" } & \multirow{2}{*}{ مستوي } & \multirow{2}{*}{ الدرجية } & \multicolumn{2}{|c|}{ المجموعة الضابطة } & \multicolumn{2}{|c|}{ المجمو عة التجريبية } & \multirow{2}{*}{ المسابقة } \\
\hline & & & $\varepsilon$ & $P$ & $\varepsilon$ & p & \\
\hline$\cdot, \varepsilon$. & ... & 01 & $r, 90$ & $17, .7$ & $r, O Y$ & 17,1 . & دفح الجلّة \\
\hline., 17 & & & T,ז T & $T, \cdot r$ & $r, \sum \wedge$ & 14,15 & رمى الرمح \\
\hline
\end{tabular}

قيمة " ت " الجدولية عند مستوى ( 0., •) = TV, T الدلالة الطرف الواحد

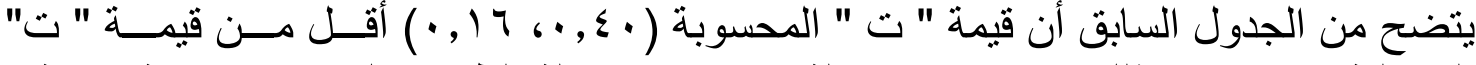

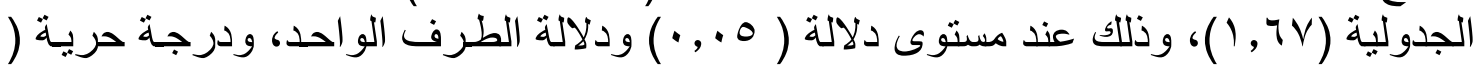
و هذا يبين تكافؤ المجمو عتين فى مستوى الأداء المهارى لمسابقات الرمى ( دفع الجلة. 
جدول (؛)

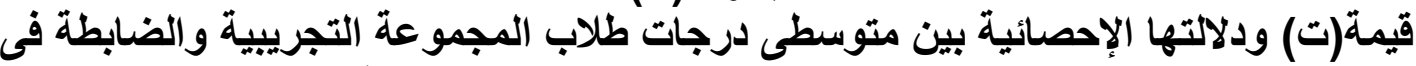

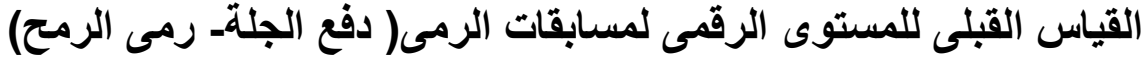

$7 \cdot=\dot{0}$

\begin{tabular}{|c|c|c|c|c|c|}
\hline \multirow{2}{*}{ "المحسوبة "تة } & \multicolumn{2}{|c|}{ المجموعة الضابطة } & \multicolumn{2}{|c|}{ المجموعة التجريبية } & \multirow{2}{*}{ لمسابقة } \\
\hline & $\varepsilon$ & م & $\varepsilon$ & م & \\
\hline ., YO & $\cdot, 94$ & $\varepsilon, \wedge 0$ & $\cdot, V T$ & $\varepsilon, 91$ & دفع الجلة \\
\hline., 10 & $1, \varepsilon \varepsilon$ & $1 \varepsilon, \cdot 7$ & $1, \wedge 9$ & $1 \varepsilon, 1 T$ & رمى الرمح \\
\hline
\end{tabular}

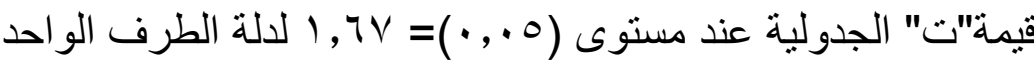

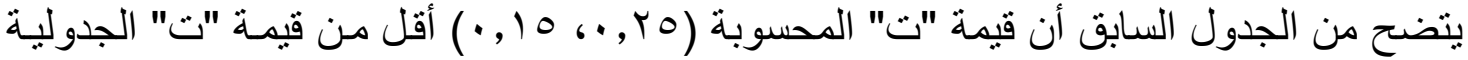

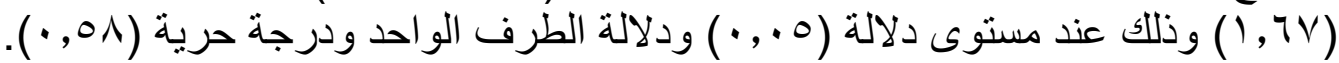

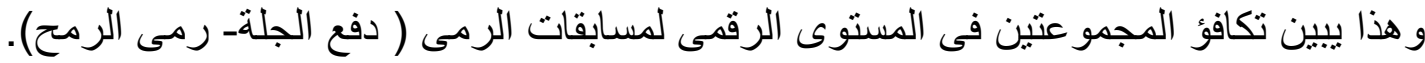

أدوات البحث:

تتطلب طبيعة البحث استخدام أدوات متعددة يمكن تقسيمها كما يلى:

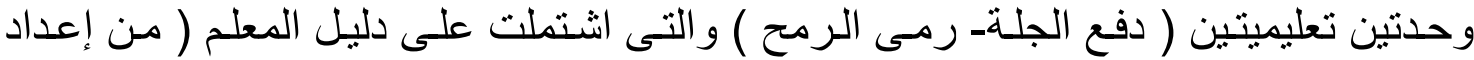

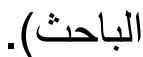

اختبـار ات لقيـاس الصـفات البدنبـة المرتبطـة بمسـابقتى دفع الجلـة ورمسى الرمح لـى طـلاب

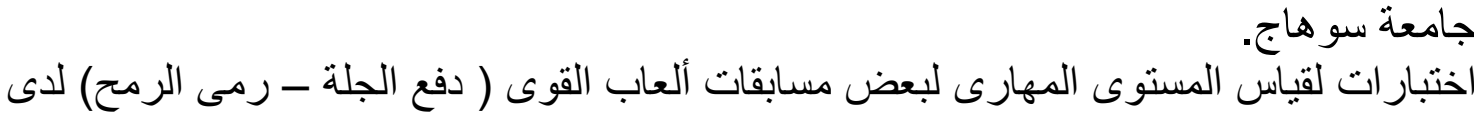

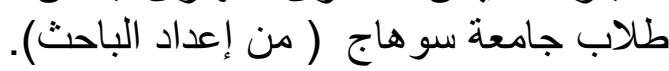

وللتحقق من صحة فروض البحث سار البحث فى الخطوات التالية:

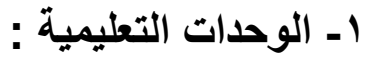

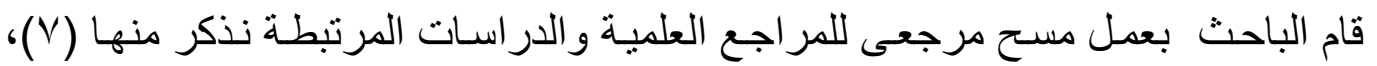

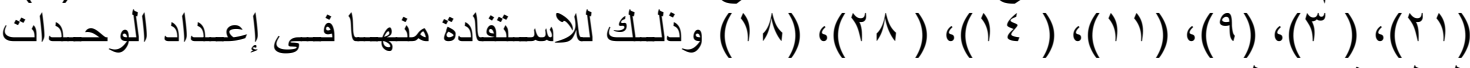

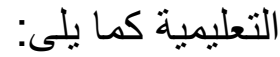

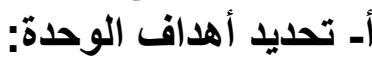

كان الهدف الأساسى من الوحدات التعليمية التى تم إعدادها هو تحسين بعض الصغ الصفات البداتينـة

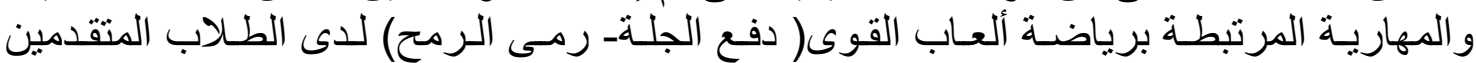

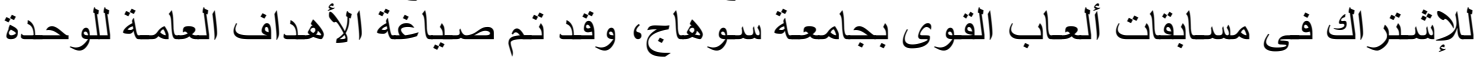

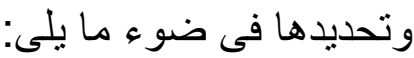

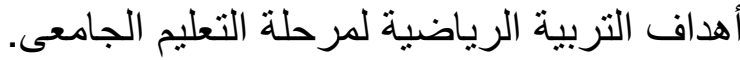

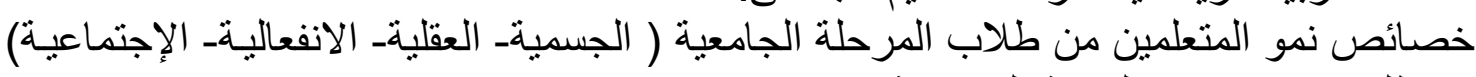
ومتطلباتها من بر امج التربية الرياضية مينة

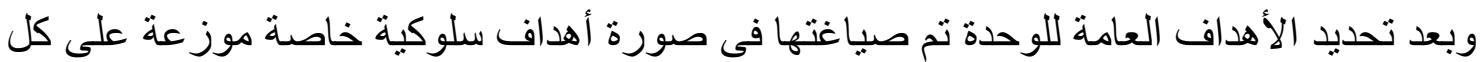

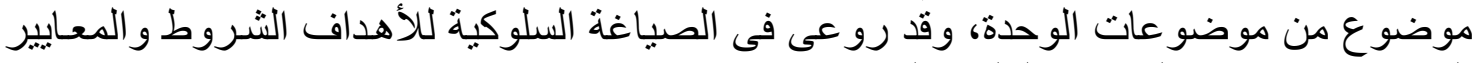

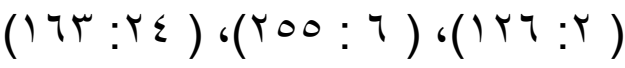

الموضحة بعدد من المر اجع العلمية المتخصصة وفئ 
ب- اختيار محتوى الوحدة:

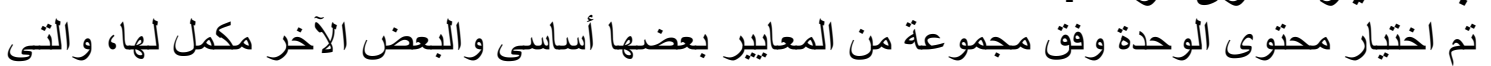

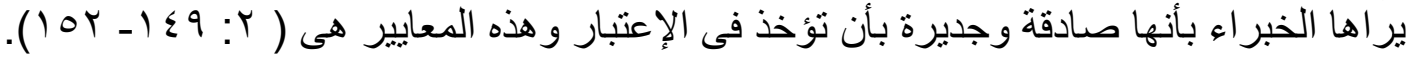

ا - المعايير الأساسية وتثمل:

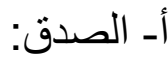

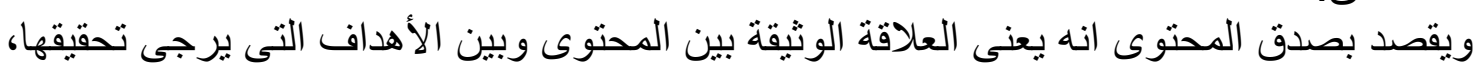
كما بعنى أيضاً إلى أى مدى يعكس هذا المحتوى المعرفة العلمية المعاصرة.

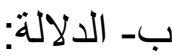
ويقصد بدلالة المحتوى اهميته بالنسبة للمجال المعرفى الذى بنتمى إلبه، ومـا إذا كان أساسياً لـه قدرة تطبيقية و اسعة.

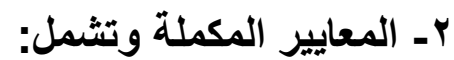
أـ تلبية احتياجات المتعلم

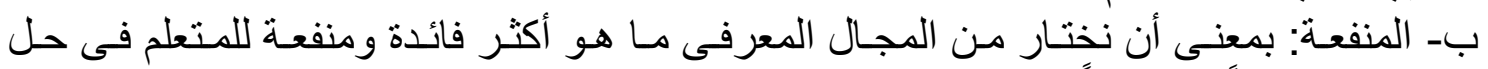
مشكلاته حاضر اً ومستقبلاً.

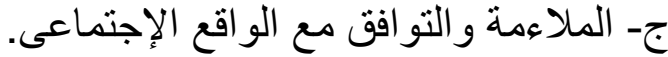

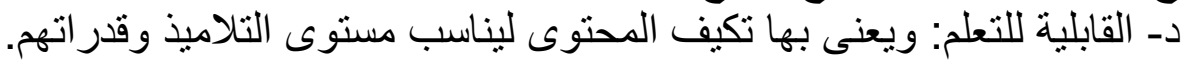
ج- تنظيم محتوى الوحدة:

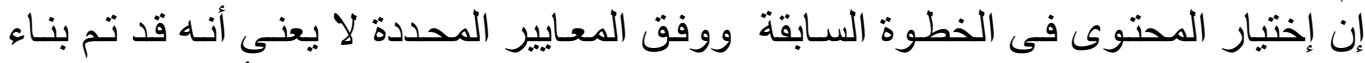

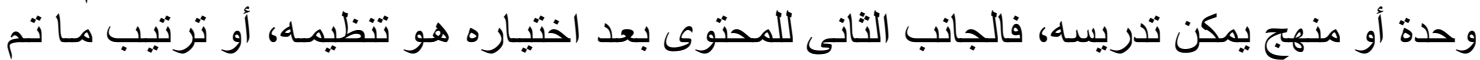

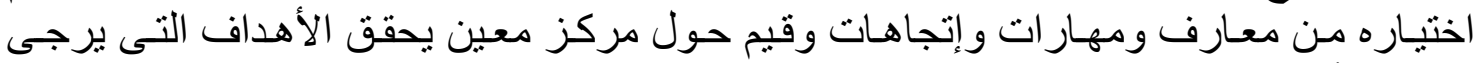
تحقيقها بأكبر قدر من الفاعلية و الكفاية الممكنة

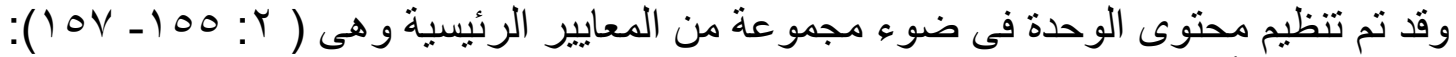

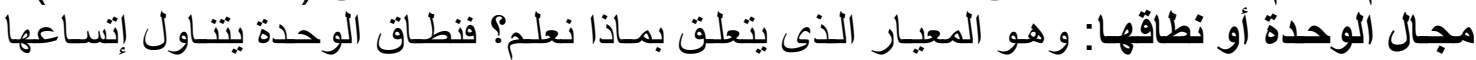
و عمقها و المجالات التى تتضمنها، ومدى العمق فى تناول هذه المجالات.

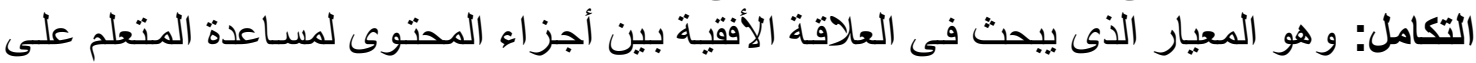

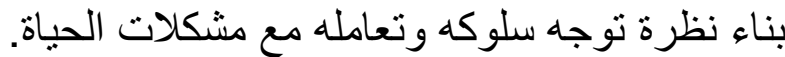

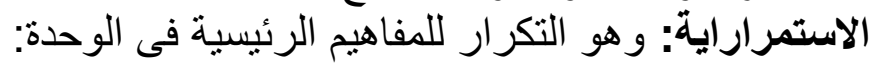

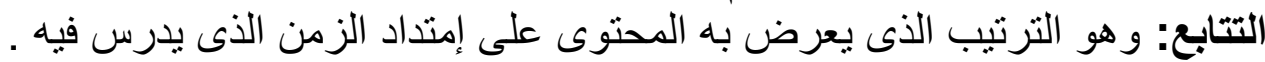

د- تحديا أنشطة التعليم والتعلم: زودت الوحدة التعليمية بالعديد من أنشطة التعليم والتعلم التى يقوم بها التها المتعلمين بمسـاعدة

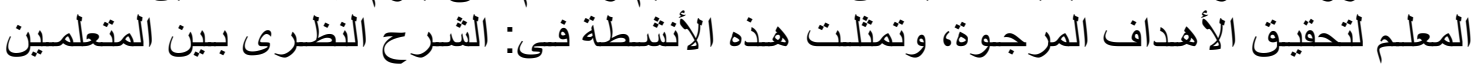

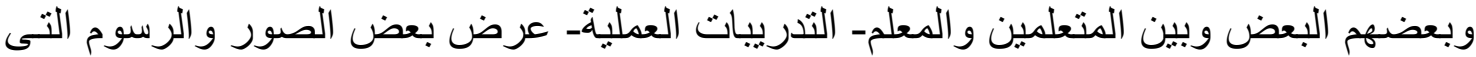

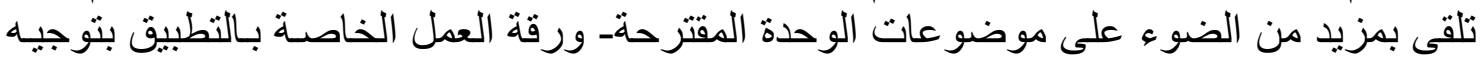

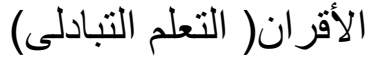




\section{تم استخدام نوعين من التقويم فى الوحدة المقترحة هما:

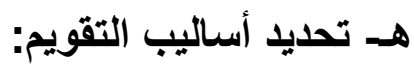

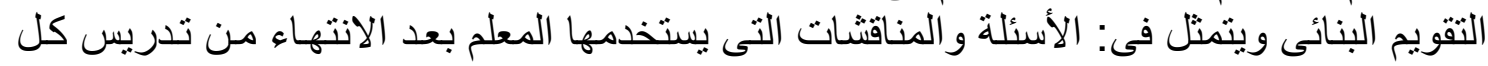

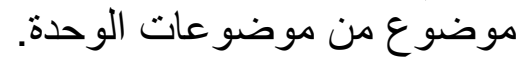

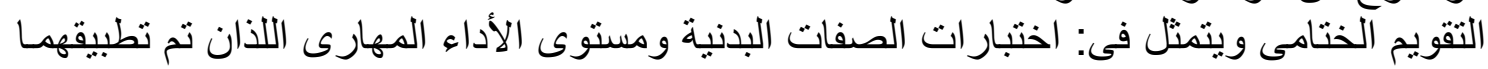

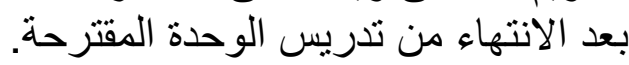

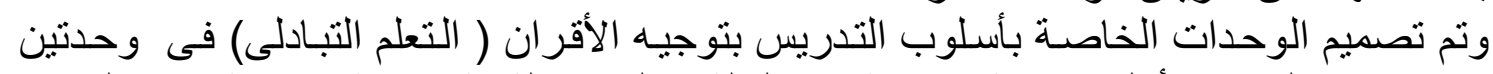

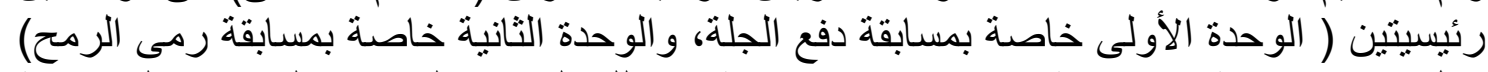

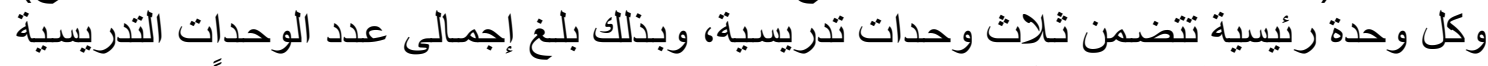

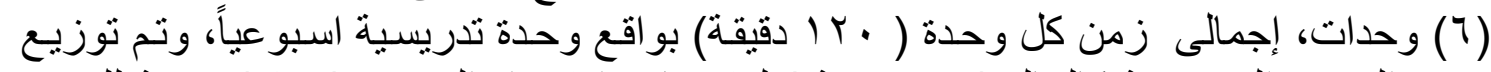

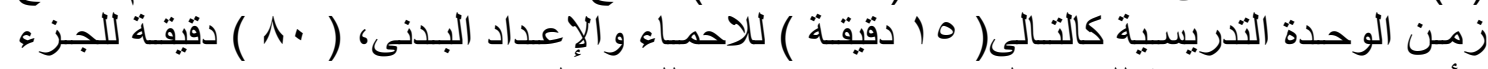

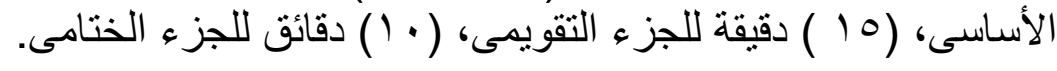

ورقة العمل الخاصة بأسلوب التطبيق بتوجيه الأقران( التعلم التبادلى):

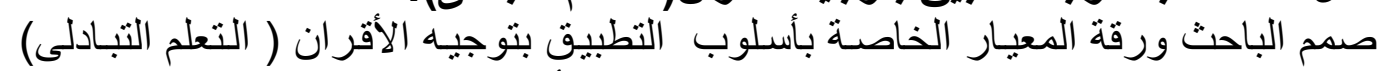

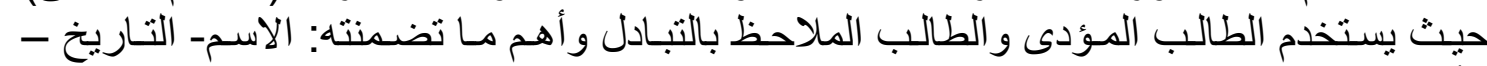

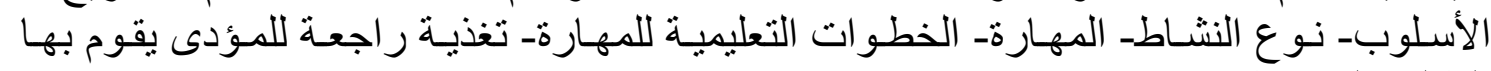

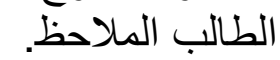

\section{التجربة الاستطلاعية للوحدة المقترحة:}

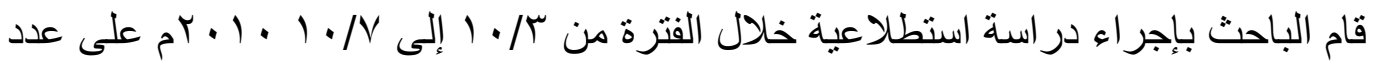

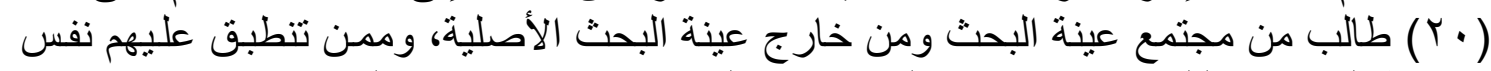

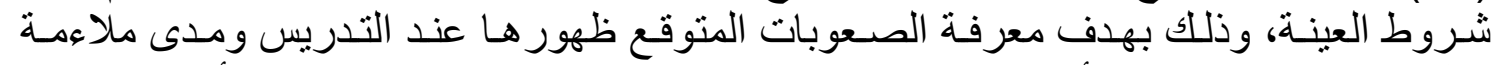

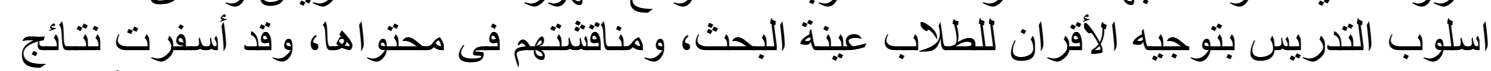

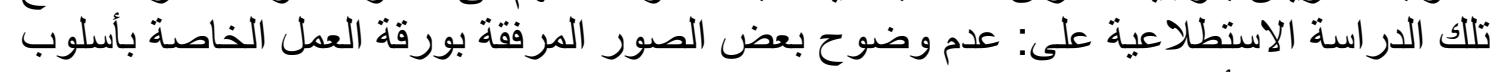

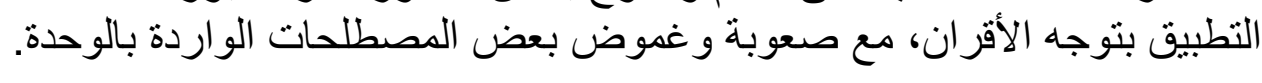

وقام الباحث بإجر اء التعديلات الخاصة ببعض الدصطلحات الغامضة الواردة بالوحدة وتم تناولها

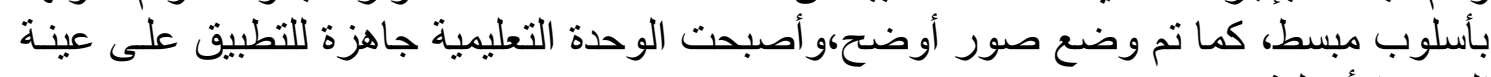

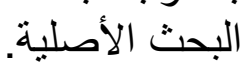

r ـ اختبارات الصفات البذنية الخاصة بمسابقات الرمى (دفع الجلةّـ رمى الرمح):

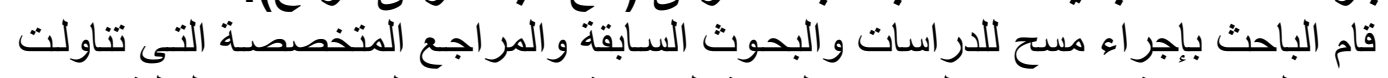

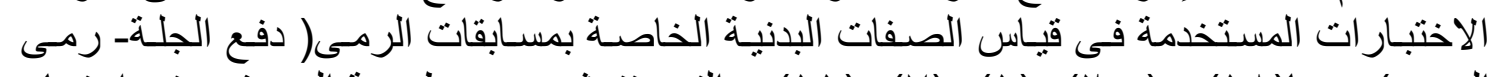

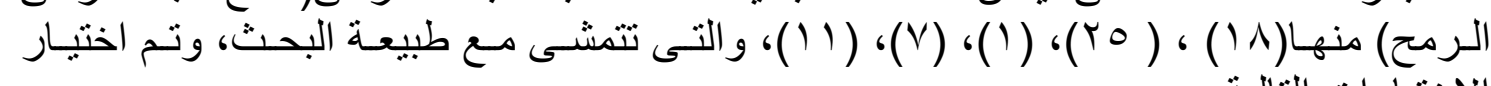

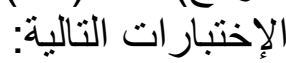

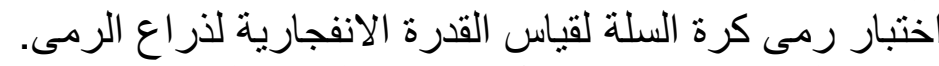

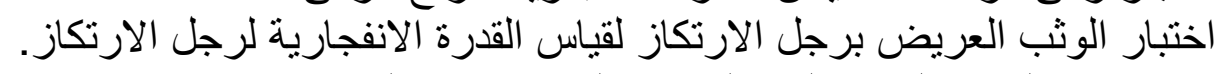

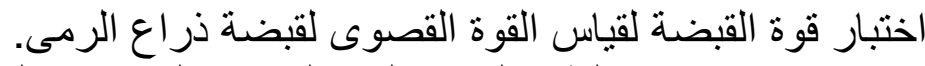

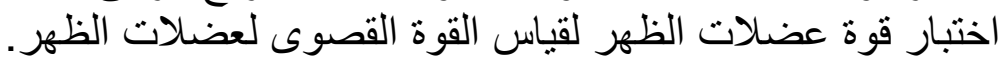
اختبار نيلسون للسرعة الحركية لقياس السر عة الحركية للذراعين. 
اختبار اللمس السفلى الجانبى لقياس المرونة الديناميكية للعمود الفقرى.

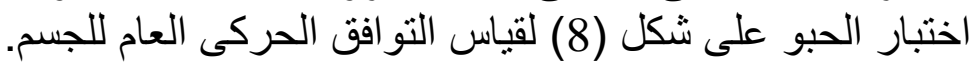

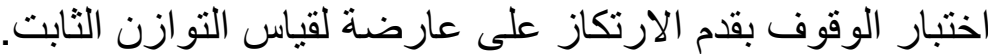

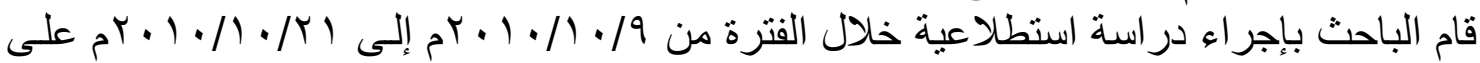

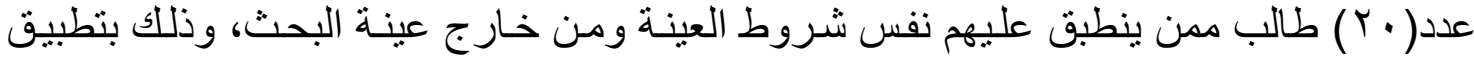
اختبار ات الصفات البدنية لحساب الصدق و الثبات.

المعاملات العلمية للاختبارات البذنية:

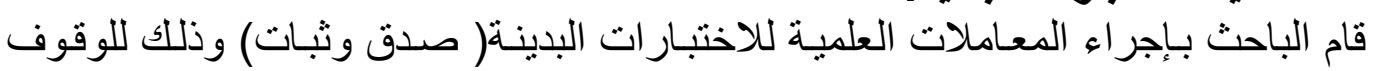
على مدى صلاحية الاختبار ات للتطبيق على عينة البحث.

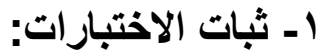

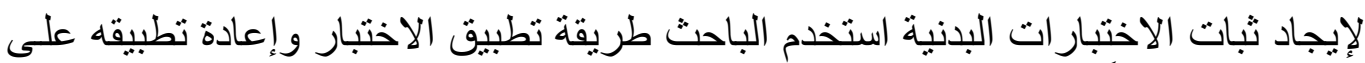

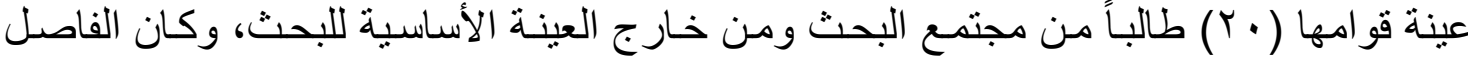

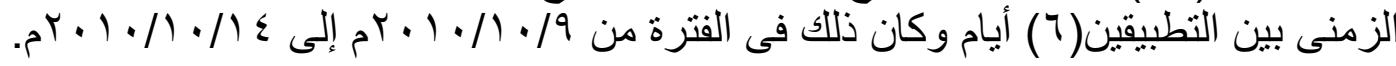

\section{(0) (0)}

معاملات الارتباط بين التطبيق الأول والثانى للاختبارات البذنية الخاصة بمسابقة الرمى حئ

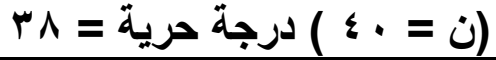

\begin{tabular}{|c|c|c|c|c|c|c|c|}
\hline \multirow{2}{*}{ الثبات } & \multirow{2}{*}{ الارتباط } & \multicolumn{2}{|c|}{ التطبيق الثانى } & \multicolumn{2}{|c|}{ التطبيق الأول } & \multirow{2}{*}{ القياس } & \multirow{2}{*}{ الاختبارات } \\
\hline & & $\varepsilon$ & b & $\varepsilon$ & 5 & & \\
\hline$\cdot, 79$ & $\cdot, 0 \leqslant$ & 1,10 & $1 \cdot, \wedge$. & $1, Y_{9}$ & $1 \cdot, \lambda \Gamma$ & متز & رمى كرة سلة \\
\hline$\cdot, \mathrm{\vee} \wedge$ & ., $7 \varepsilon$ & $\cdot, 17$ & $1, \varepsilon$. & $\cdot, 19$ & $1, \varepsilon r$ & متر متر & الوثب العريض برجل الارتكاز \\
\hline$\cdot, \wedge \varepsilon$ & $\cdot, \mathrm{VY}$ & $Y \cdot, \cdot V$ & YI,Yo & $r, . T$ & YI,Y. & كجم & قوة القبضة \\
\hline$\cdot, 94$ & $\cdot, \wedge \mathrm{V}$ & 1,91 & 1,70 & $r, \cdot \Lambda$ & YI,T. & كجم & قوة عضلات الظهر \\
\hline$\cdot, \wedge 7$ & $\cdot, \mathrm{VT}$ & Y, \&. & $r \leqslant, 0$. & $Y, 1 \varepsilon$ & $Y \varepsilon, 00$ & 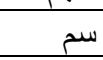 & نيلسون للسرعة الحركية \\
\hline$\cdot, 94$ & $\cdot, \wedge \wedge$ & $r, Y$. & V,ro & $r, 11$ & $v, 00$ & بالعدد & اللمس السفلى الجانبى \\
\hline$\cdot, V Y$ & $\cdot, 04$ & 0,0 & or,9. & $\varepsilon, 94$ & Or,Yo & ثانية & الحبو \\
\hline$\cdot, 94$ & $\cdot, \wedge \wedge$ & $1,1$. & ז,ч. & 1,0 & r, ro & ثانية & 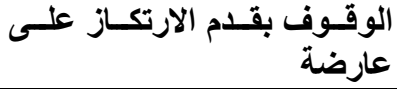 \\
\hline
\end{tabular}

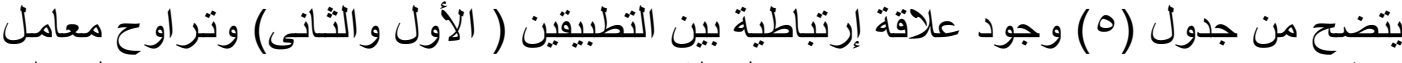

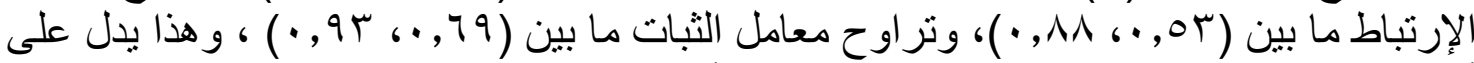

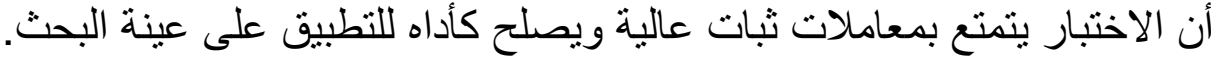

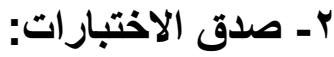

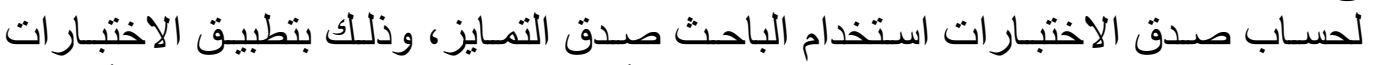

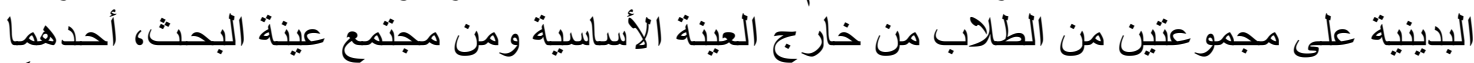

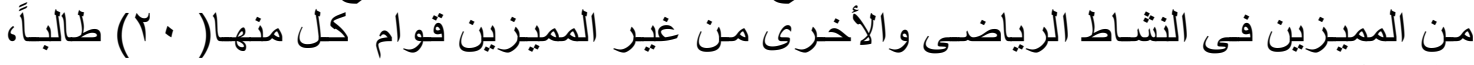
و الجدول التالى يوضح النتيجة. 


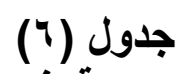

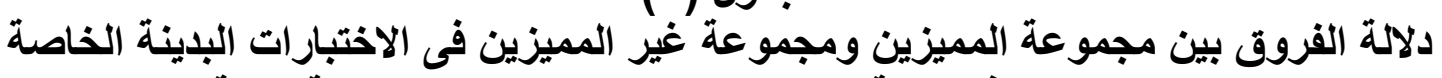

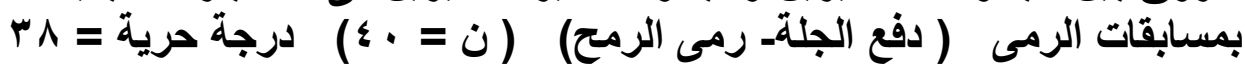

\begin{tabular}{|c|c|c|c|c|c|c|c|}
\hline \multirow{2}{*}{ المحسوبة) } & \multirow{2}{*}{ الفروق الفق } & \multicolumn{2}{|c|}{ مجموعة غير } & \multicolumn{2}{|c|}{ محمو عة المميزين } & \multirow{2}{*}{ القياس } & \multirow[t]{2}{*}{ الاختبارات } \\
\hline & & $\varepsilon$ & b & $\varepsilon$ & b & & \\
\hline$T V, \Lambda T$ & $V, r r$ & $\overline{1, Y A}$ & $1 \cdot, \lambda r$ & $1, r$ & 11,1 & متر & رمى كرة سلة \\
\hline$v, v \cdot$ & $\cdot, r V$ & $\cdot, 1 \wedge$ & $1, \varepsilon r$ & $\cdot, 1$ & $1, \vee 9$ & متز & الوثب العريض برجل الارتكاز \\
\hline $1 r, 09$ & $\mathrm{v}, \mathrm{T}$. & $r, . T$ & ri,r. & $1, V r$ & $\lceil\wedge, \wedge$ & كجم & قوة القبضة \\
\hline $11, \wedge$. & $1 \cdot, 0$ & $r, \cdot \wedge$ & r, ז. & ץ, זی & rr,l & كجم & قوة عضلات الظهر \\
\hline $1 \%, 10_{-}$ & 9, ro_ & r,Ir & $r \leqslant, 00$ & t, to & $10, r$ & 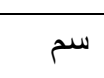 & نيلسون للسرعة الحركية \\
\hline Ir, ro & $\wedge, \varepsilon$. & $r, 11$ & $\gamma, \infty 0$ & $r, 1 \Lambda$ & $\begin{array}{r}10,9 \\
0\end{array}$ & بالعدد & اللمس السفلى الجاتبى \\
\hline $1 \cdot, \vee \vee \wedge_{-}$ & IY, & $\varepsilon, q$ & or,q. & 1,04 & $\varepsilon 1,0$ & ثانية & الحبو \\
\hline $1 \leqslant, 97$ & $\mathrm{v}, \mathrm{O}$. & 1,01 & r, ro & 1,70 & $\begin{aligned} 1 \cdot, v \\
0\end{aligned}$ & ثانية & 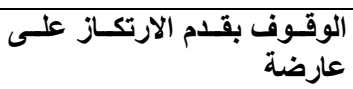 \\
\hline
\end{tabular}

يتضح من جدول (آ) وجود فروق ذات دلالة إحصائية بين مجمو عة المميزين ومجموعة غير

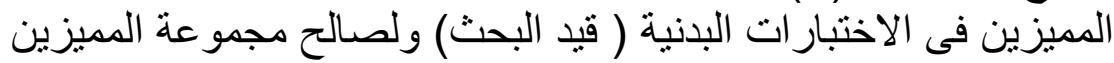

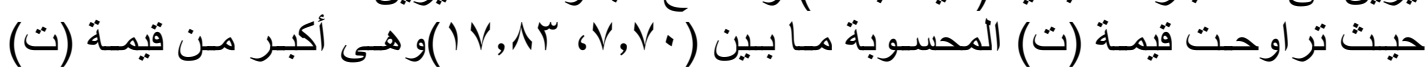

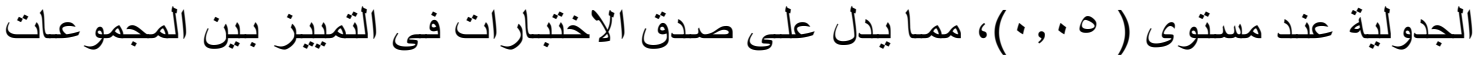

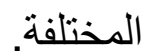

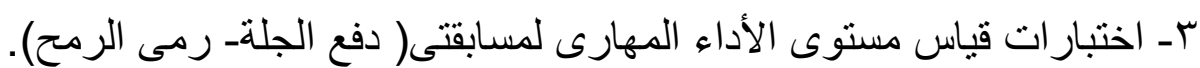

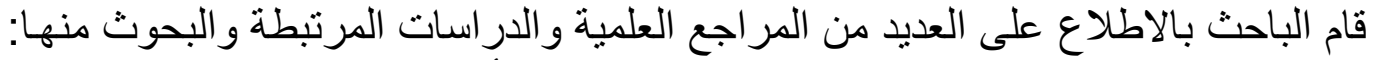

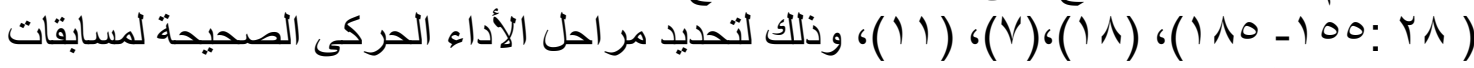

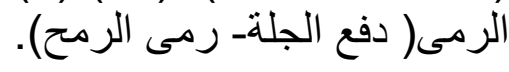

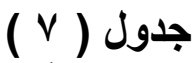

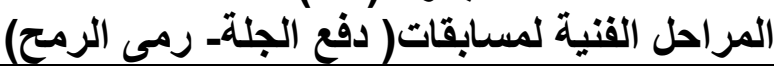

\begin{tabular}{|c|c|c|c|}
\hline لكل المكونة & المراحل الفنية" مراحل الأداء الحركى" & المسابقة & p \\
\hline « & 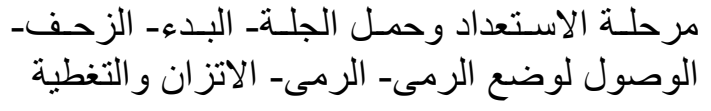 & دفع الجلة & 1 \\
\hline rr & 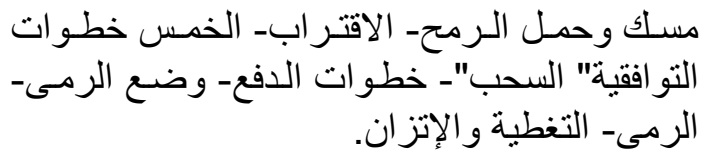 & الرمح & r \\
\hline
\end{tabular}




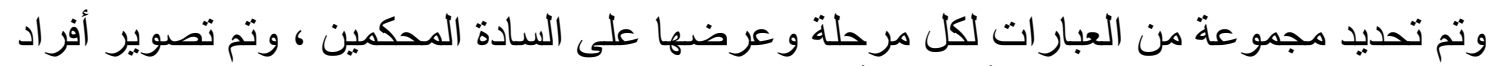

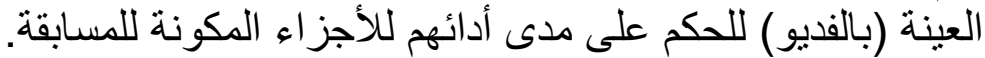

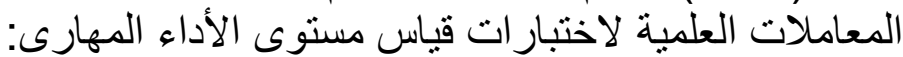

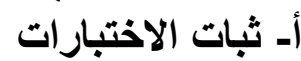
لإيجاد ثبات الاختبار ات المهارية استخدم الباحث طريقة تطبيق الاختبار و إعادة تطبيقة على الإنى

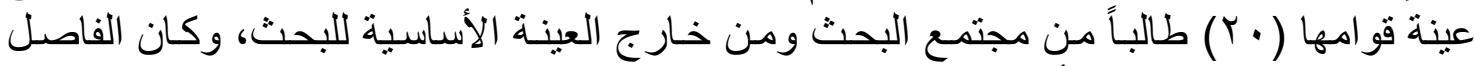

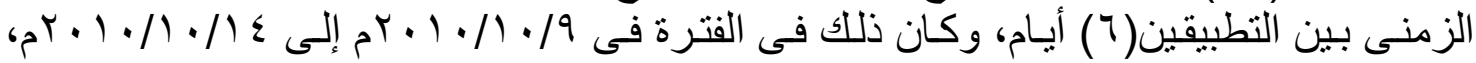

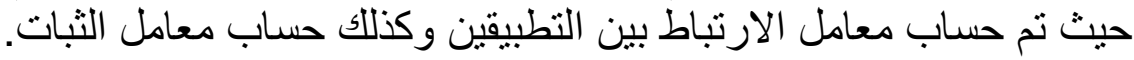

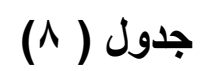

معامل الارتباط بين التطبيقين الأول والثانى لاختبارات قياس مستوى الأداء المهارى لمسابقات

"

$$
\text { الرمى( دفع الجلةـ رمى الرمبح) }
$$

\begin{tabular}{|c|c|c|}
\hline الثبات & معامل الارتباط & المسابقة \\
\hline$\cdot, 90$ &., 94 & دفع الجلة \\
\hline$\cdot, 91$ & $\cdot, \wedge \varepsilon$ & رمى الرمح \\
\hline
\end{tabular}

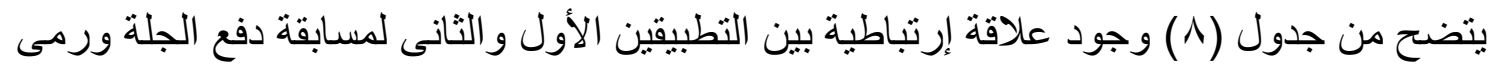

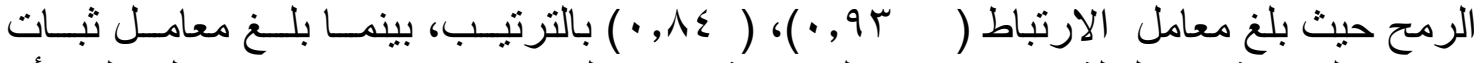

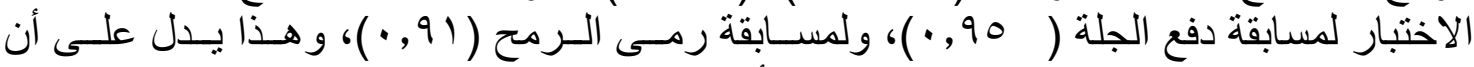
الاختبار يتمتع بمعاملات ثبات عالية ويصلح كأداه للتطبيق على عينة البردة البحث.

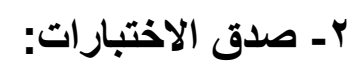

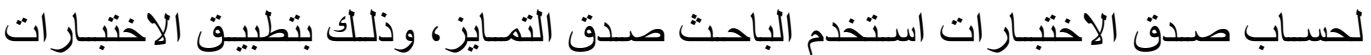

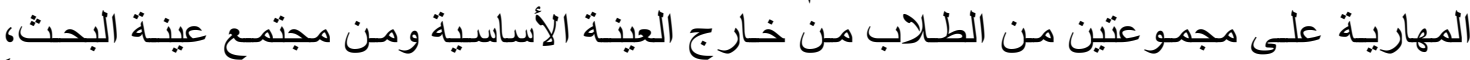

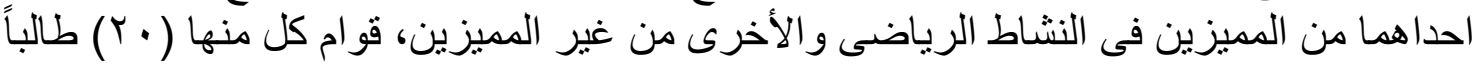
و الجدول التالى يوضح النيزين فئة النئ.

جدول (9) جموعة (9)

\begin{tabular}{|c|c|c|c|c|c|c|}
\hline \multirow{2}{*}{ قالمحسوبة) } & \multirow[t]{2}{*}{ الفروق } & \multicolumn{2}{|c|}{ مجموعة غيز المميزين } & \multicolumn{2}{|c|}{ المميزين } & \multirow[t]{2}{*}{ الاختبارات } \\
\hline & & $\varepsilon$ & م & $\varepsilon$ & م & \\
\hline $1 \pi, 09$ & o & $\varepsilon, \cdot V$ & 10,00 & 1,70 & r^,q. & دفع الجلة \\
\hline $1 \cdot, \varepsilon r$ & 1,70 & $r, V$. & 11,90 & Y,OE & $r \cdot, T$. & رمى الرمح \\
\hline
\end{tabular}

دلالة الفروق بين مجموعة المميزين ومجموعة غيرالمميزين فى اختبارات قياس مستوى الأداء

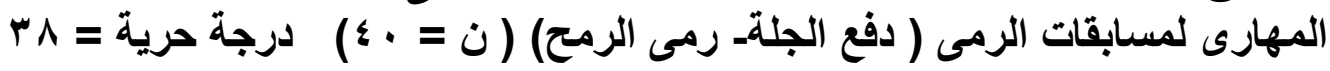

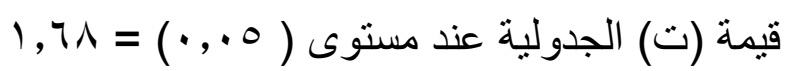




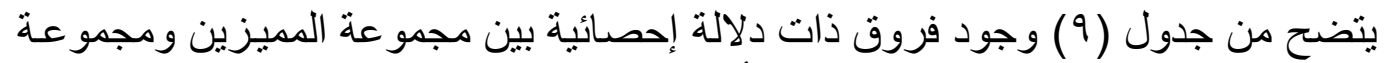

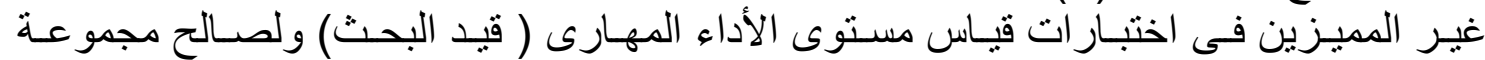

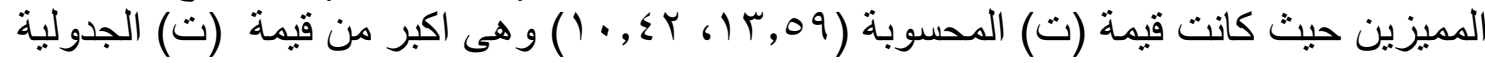

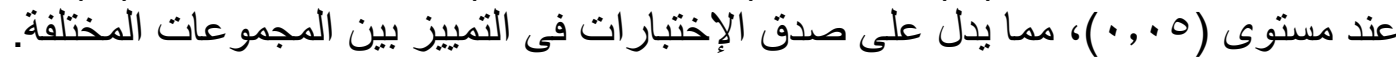

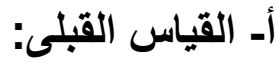

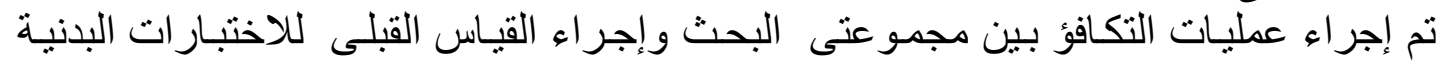

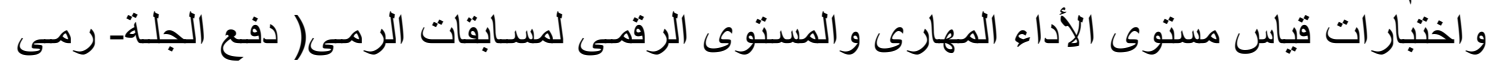

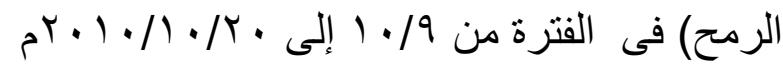

بـ تنفيذ التجربة الأساسية للبحث:

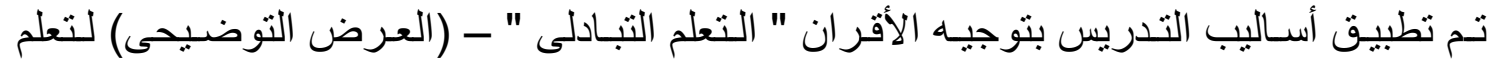

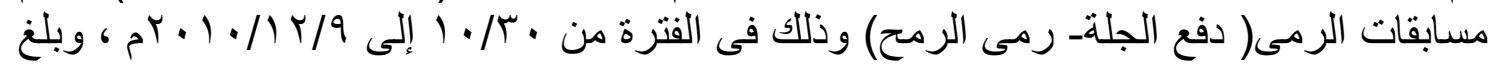

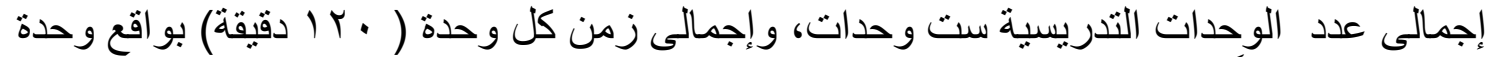

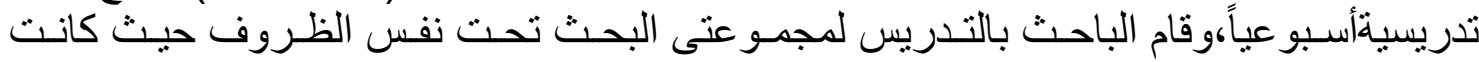

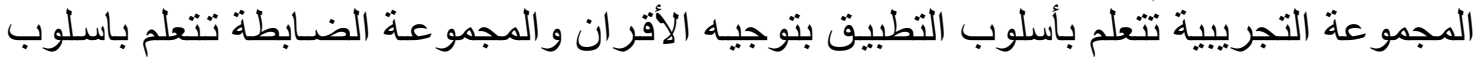

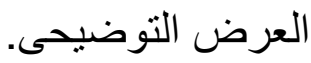

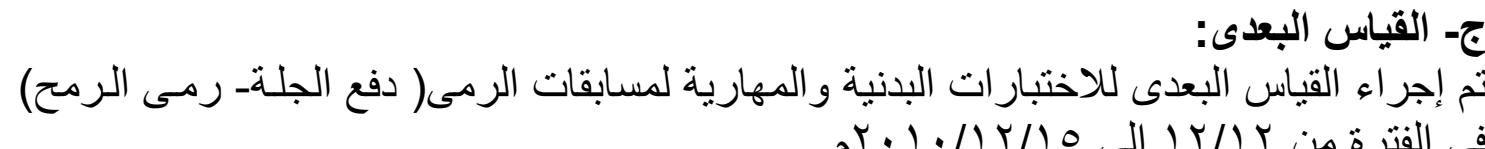

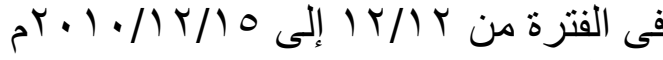

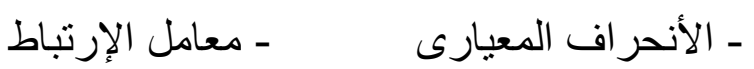

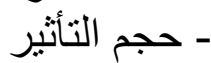

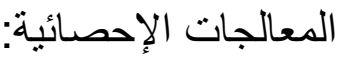

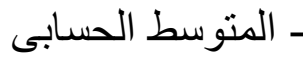

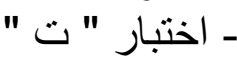

نتائج الاراسة التجريبية

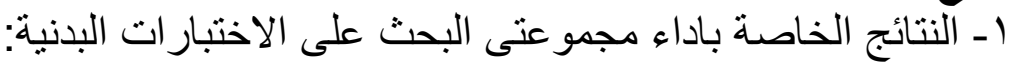

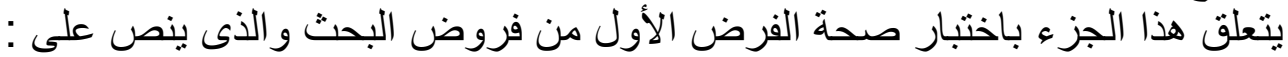

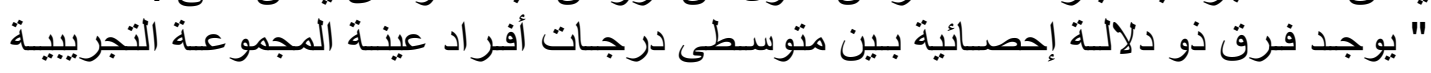

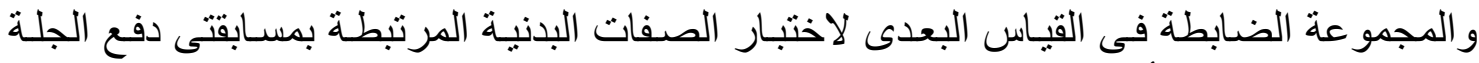
ورمى الرمح لصالح أفراد عينة المجموعة التجدي لإيبار التيبة " .

و لإختبار صحة هذا الفرض تم استخدام اختبار " ت" لحساب دلالة الفرق بين متوسطين مرتبطين

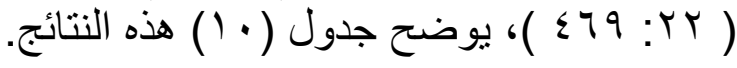




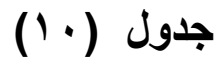

قيمة"ت"ودلالتها الإحصائية بين متوسطى درجات طلاب المجموعة التولة التجريبية والضابطة فى التي

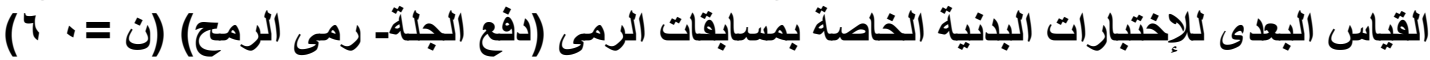

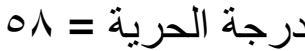

\begin{tabular}{|c|c|c|c|c|c|c|c|c|c|}
\hline \multirow{2}{*}{ الالال } & \multicolumn{2}{|c|}{ حجم التأثير } & \multirow{2}{*}{ قالمحسوب } & \multicolumn{2}{|c|}{ المجموعة الضطة } & \multicolumn{2}{|c|}{ التحموعة التجريبية } & \multirow{2}{*}{ وحدة } & \multirow[t]{2}{*}{ الاختبارات } \\
\hline & D & 32 & & $\varepsilon$ & 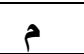 & $\varepsilon$ & 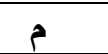 & & \\
\hline كبيرة & $1, r q$ & •,9r & rT, & $1, \cdot v$ & $11, r$ & $1, V V$ & Y), & 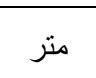 & رمى كرة سلة \\
\hline كبيرة & $1, r r$ & $\cdot, \vee \vee q$ & I \&,גז & $\cdot, 19$ & 1,0 & $\cdot, 10$ & $r, r$. & متر & الارتكازب العـريض برجـل \\
\hline كبيرة & $1, r \wedge$ & •,9r & rT,O & $\begin{aligned} r \cdot, t \\
r\end{aligned}$ & r,T & r,, 0 & rq, $\varepsilon$. & كجم & قوة القبضة \\
\hline 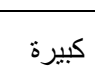 & $1, r v$ & $\cdot, \wedge 9$ & Y),9V & $1,7 V$ & ru & $\vee, \wedge \varepsilon$ & or, \&. & كجم & قوة عضلات الظهر \\
\hline كبيرة & $1, r \wedge$ & $\cdot, 94$ & r०, ११. & $r, 1 \leq$ & $\begin{array}{r}r \leqslant, 0 \\
T\end{array}$ & $r, \varepsilon)$ & Q, r & 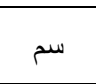 & نيلسون للسرعة الحركية \\
\hline كبيرة & $1, \varepsilon$ & $\cdot, 97$ & ru,Ar & 1,11 & 8,17 & $1,0 \leqslant$ & 19,97 & عدد & اللمس السفلى الجاتبى \\
\hline كبيرة & $1, \varepsilon$ & $\cdot, 97$ & $\leq r, O Y_{-}$ & r, r & 00,9 & $r, r \cdot$ & $r \cdot, \varepsilon r$ & ثانية & الحبو \\
\hline كبيرة كبير & 1, ro & $\cdot, \wedge \varepsilon$ & שT, & $1, Y V$ & r & $r, 1$. & $1 \cdot, \cdot r$ & ثنانية & عارضة بقام الارتكاز على \\
\hline
\end{tabular}

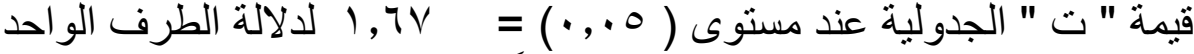

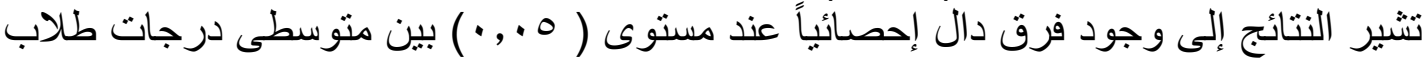

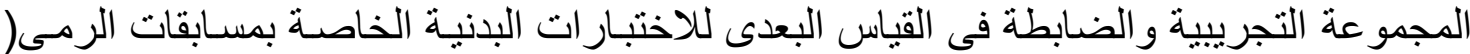

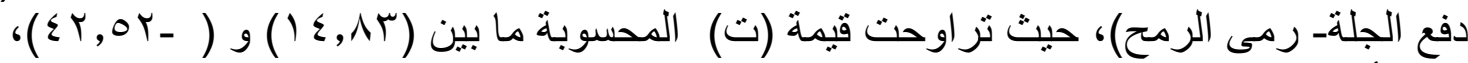

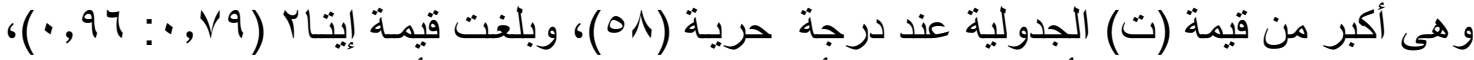

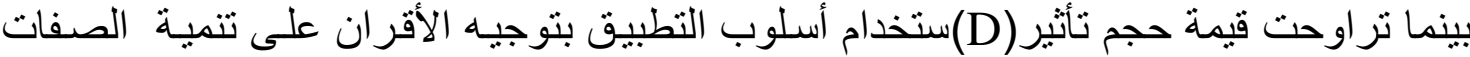

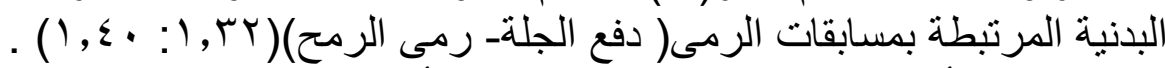
وبذلك أمكن التحقيق من صحة الفرض الرفات الأول من فروض الرغ البحث

r- النتائج الخاصة بأداء مجمو عتى البحث على اختبار ات الأداء المهارى:

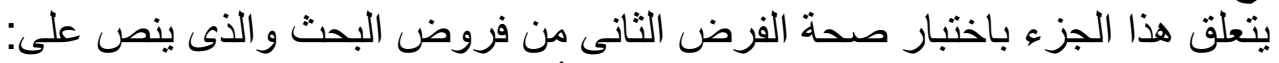

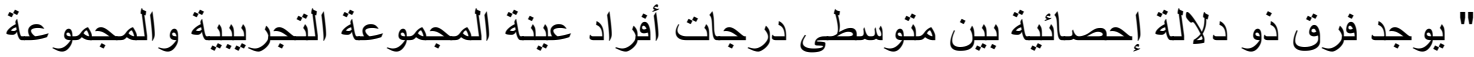

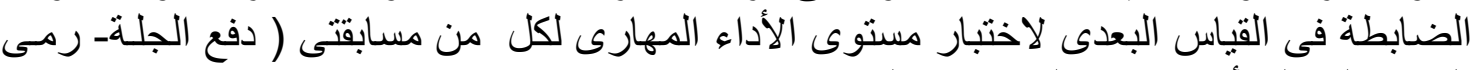

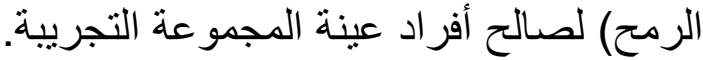
و لاختبار صحة الفرض تم استخدام اختبار (ت) لحساب الحنة دلالة الفرق بين متوسطين مرتبطين، يوضح الجدول (1) (1)، (Y) (I) هذه النتائج. 


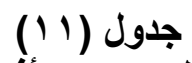

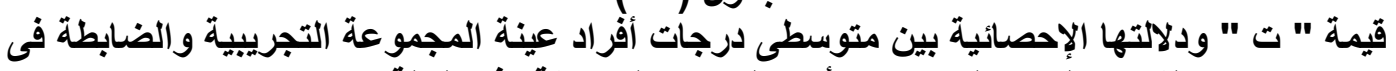

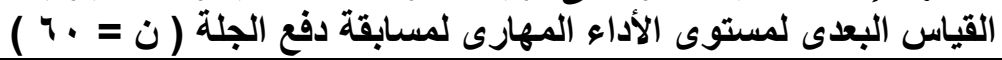

\begin{tabular}{|c|c|c|c|c|c|c|c|c|c|}
\hline \multirow[t]{2}{*}{ الدلالة } & \multicolumn{2}{|c|}{ حجم التأثير(•) } & \multirow{2}{*}{ قالمحسوبة (ت) } & \multirow{2}{*}{ الدلالة } & \multicolumn{2}{|c|}{ الضجابطوعة } & \multicolumn{2}{|c|}{ التجريبية } & \multirow[t]{2}{*}{ المسابقة } \\
\hline & D & 32 & & & $\varepsilon$ & م & $\varepsilon$ & r & \\
\hline كبيرة & $1, r q$ & . 94 & $r \tau, r \wedge$ & 01 & سr, & 17,07 & $r, r \varepsilon$ & $\varepsilon,, \ldots$ & دفع الجلة \\
\hline
\end{tabular}

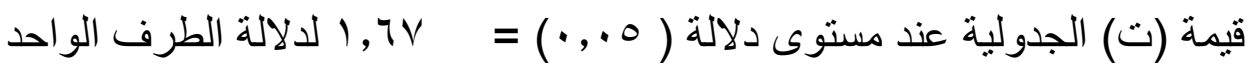

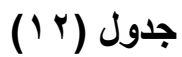

قيمة " ت" ودلالتها الإحصائية بين متوسطى درجات أفراد المجموعة التجريبية والضابطة فى القياس

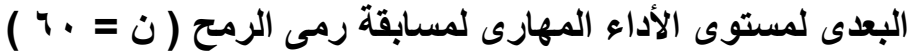

\begin{tabular}{|c|c|c|c|c|c|c|c|c|c|c|}
\hline \multirow[t]{2}{*}{ الدلالة } & \multicolumn{2}{|c|}{ حجم التأثير } & \multirow{2}{*}{ قالميــــــة (ت) } & \multirow{2}{*}{ مسلـــا } & \multirow{2}{*}{ الحرية } & \multicolumn{2}{|c|}{ الضجبطوعة المـــــــة } & \multicolumn{2}{|c|}{ التجريبية } & \multirow[t]{2}{*}{ المسابقة } \\
\hline & D & 32 & & & & $\varepsilon$ & ? & $\varepsilon$ & p & \\
\hline كبيرة & $1, \varepsilon$. & $\cdot, 90$ & r r, & $\cdot, .0$ & 01 & r, & $11, v$. & $1, r 0$ & $r 9,0 r$ & رمى الرمح \\
\hline
\end{tabular}

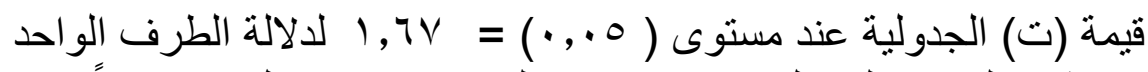

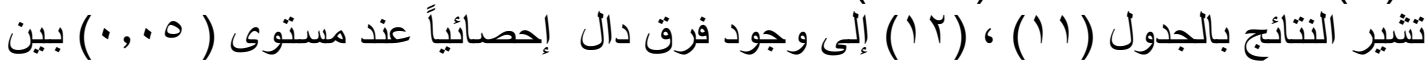

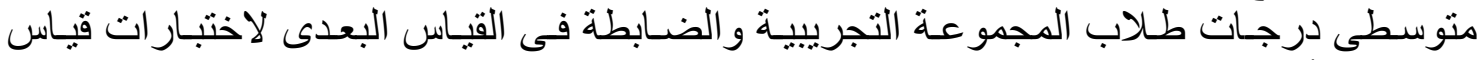

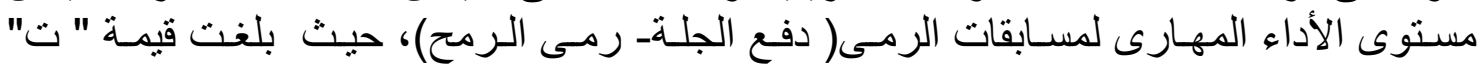

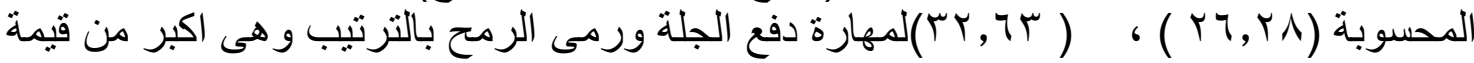

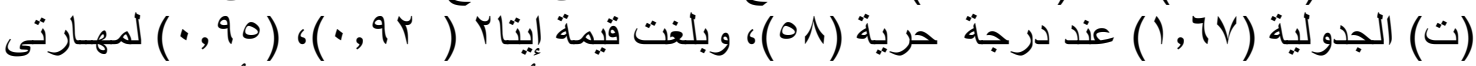

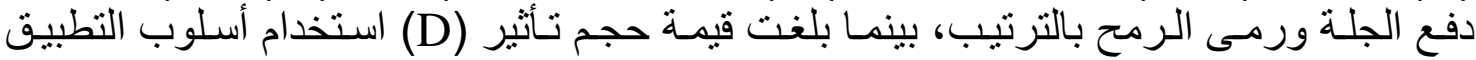

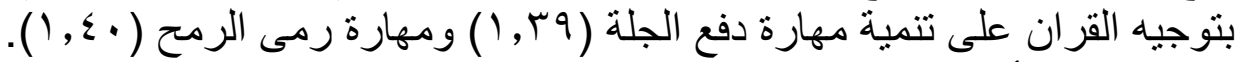

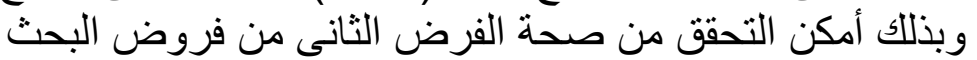

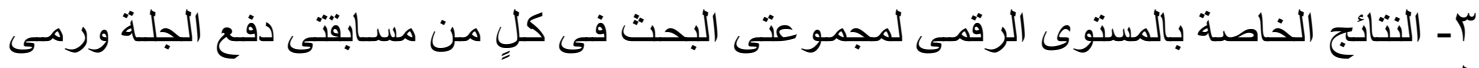
الرمح: يتعلق هذا الجزء باختبار صحة الفرض الثالث من فروض البحث و الذى ينص على : 


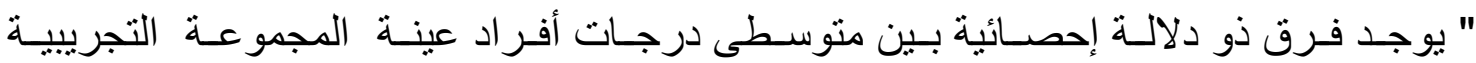

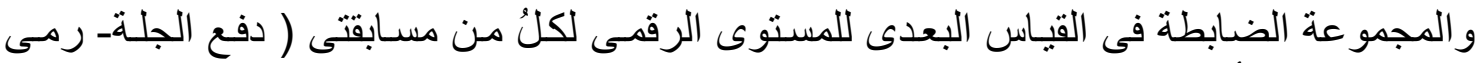

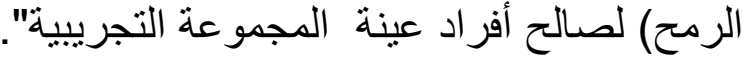

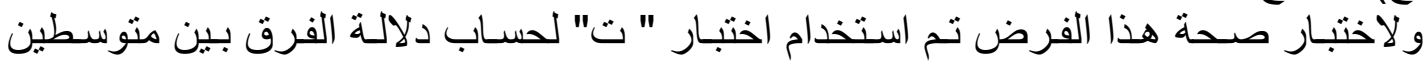
مرتبطين، ويوضح جدول (س ار ) هذه النتائج

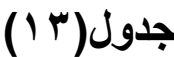

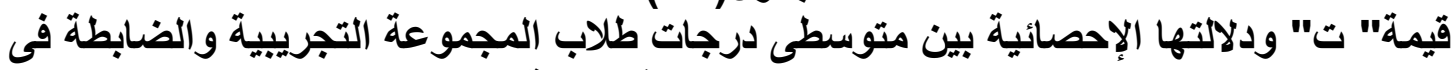

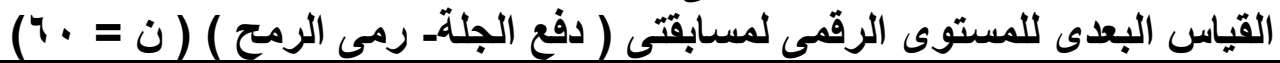

\begin{tabular}{|c|c|c|c|c|c|c|c|c|c|}
\hline \multirow{2}{*}{ الدلالة } & \multicolumn{2}{|c|}{ حجم التأثير } & \multirow{2}{*}{ قالمحسوبة) } & \multirow{2}{*}{ الحرجة } & \multicolumn{2}{|c|}{ المجموعة الضابطة } & \multicolumn{2}{|c|}{ المحموعة التجريبية } & \multirow{2}{*}{ المسابقة } \\
\hline & D & 32 & & & $\varepsilon$ & b & $\varepsilon$ & ? & \\
\hline كبيرة & $1, r 9$ & $\cdot, V T$ & IT, rT & 01 & $\cdot, \vee \wedge$ & $\leqslant, 9 \leqslant$ & $r, . T$ & १,१५ & دفع الجلة \\
\hline كبيرة & I, & $\cdot, \mathrm{VV}$ & $1 \varepsilon, \cdot V$ & 01 & $r, r q$ & $1 \leqslant, 11$ & т, , & $r \cdot, v \cdot$ & رمى الرمح \\
\hline
\end{tabular}

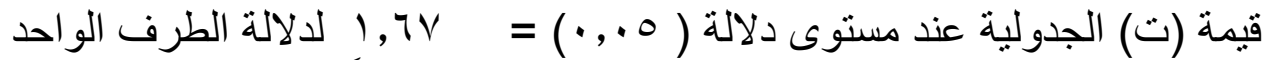

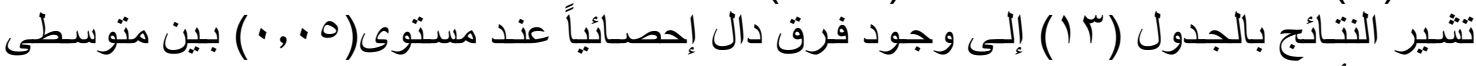

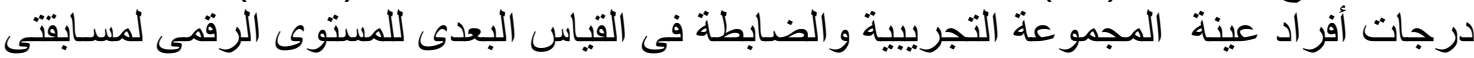

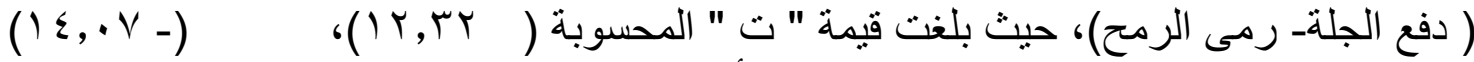

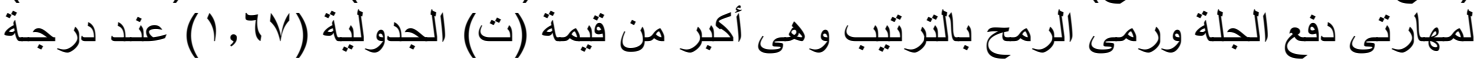

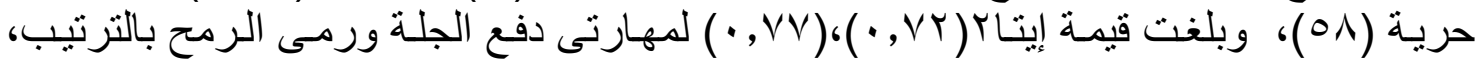

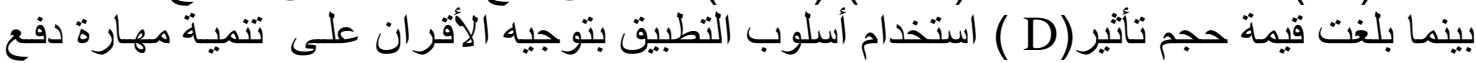

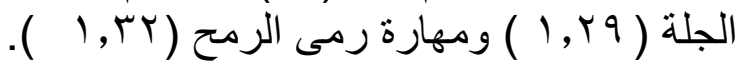
وبذلك امكن التحقق من صحة الفرض الثرد (لثالث من فروض البحث

\section{مناقشة نتائج البحث وتفسيرها:}

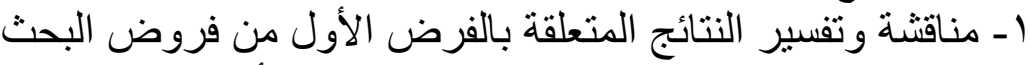

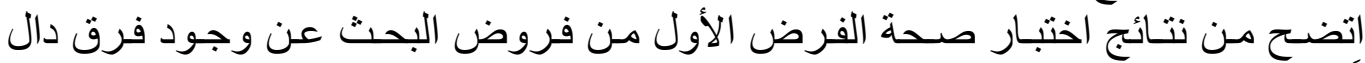

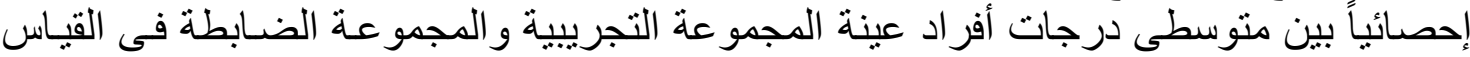

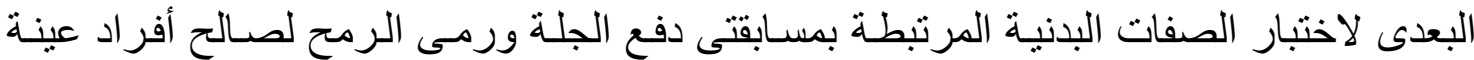

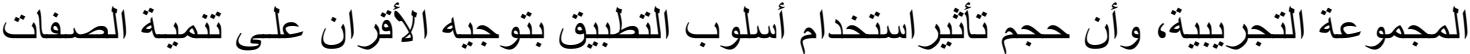
البدنية المرتبطة ببعض مهار ات العاب القوى -قبد البحثـ كان قوياً.

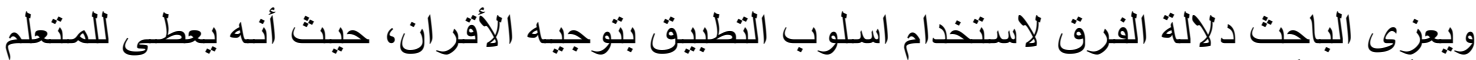

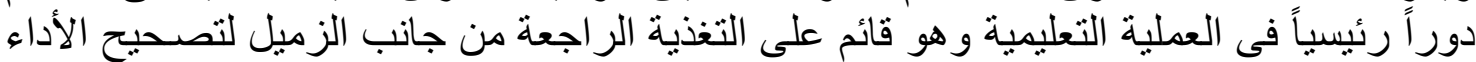

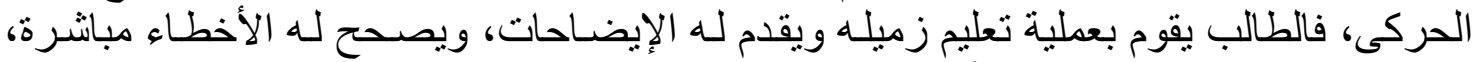
مما يساعد على تطوير وتحسين أدائهم.

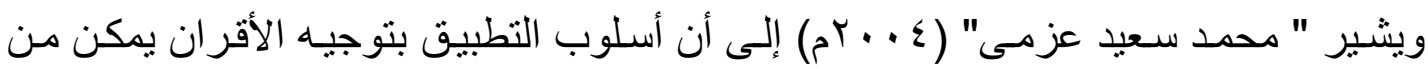

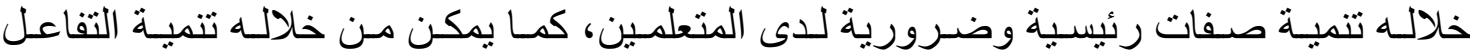




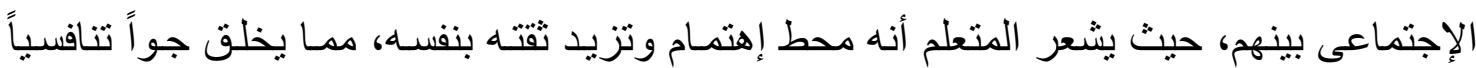

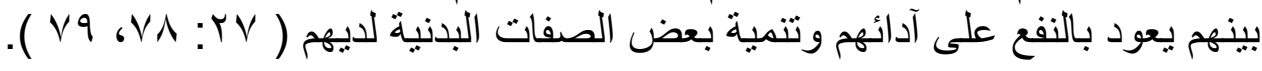

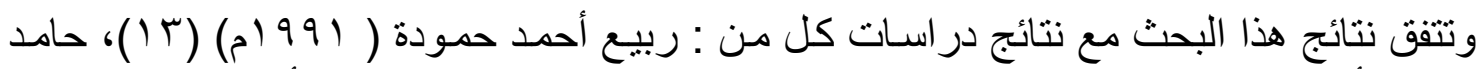

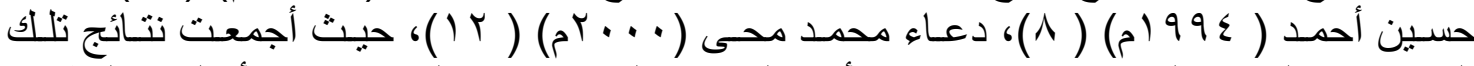
الدراسات على ان التحسن فى مستوى الأداء البدنى و الفنى يرجع إلى استخدام أسلوب التطبيق

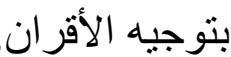

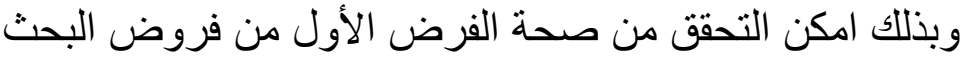

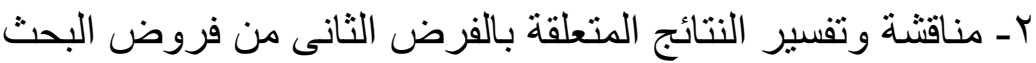

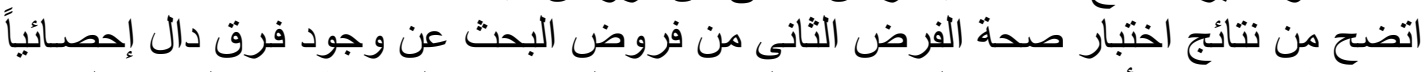

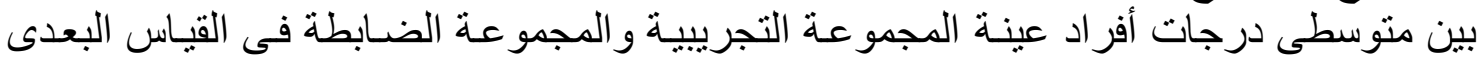

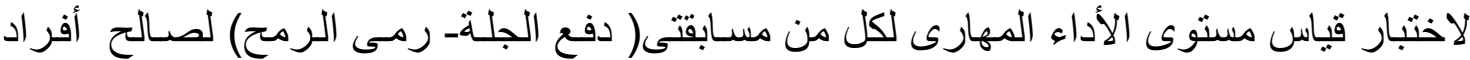

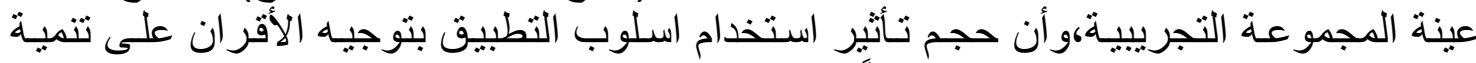

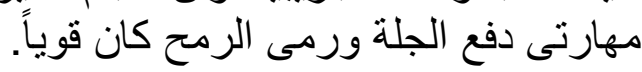

ويرجع الباحث هذه التحسن إلى التأثير الإيجابى لاستخدام أسلوب التطبيق بتوجيه الأقران، حيث أنه

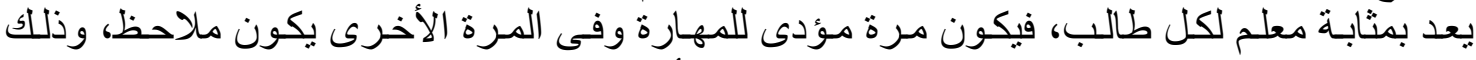

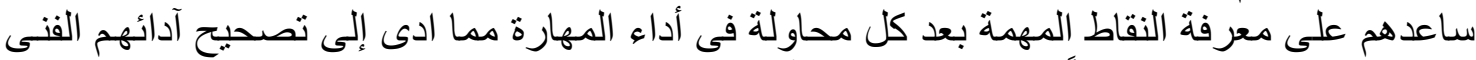

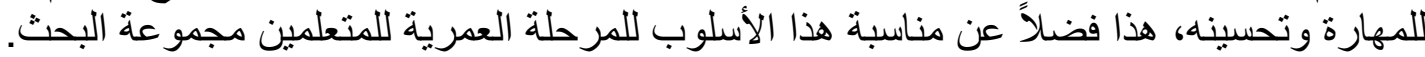

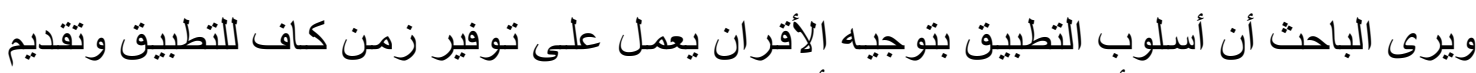

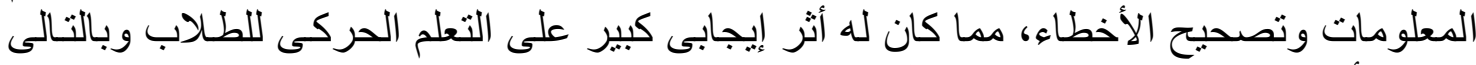
تحسين أدائهم الحركى للمهار ات قبداه البحث.

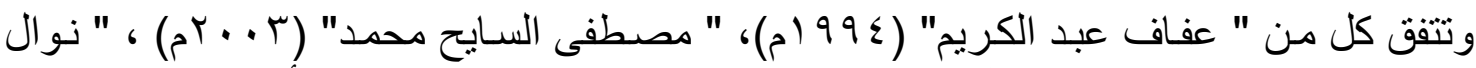

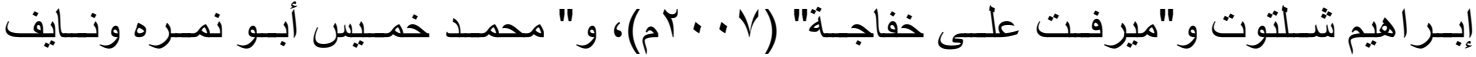

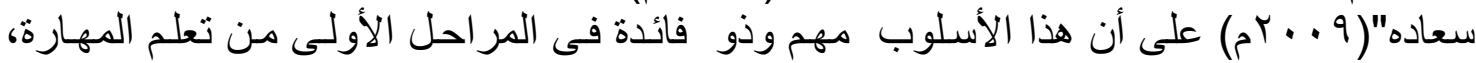

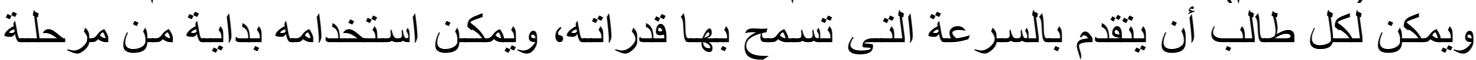

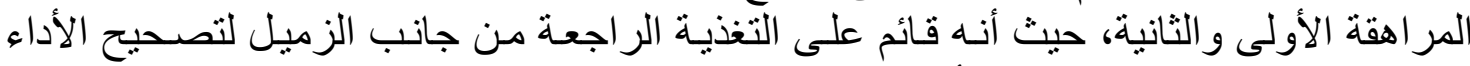

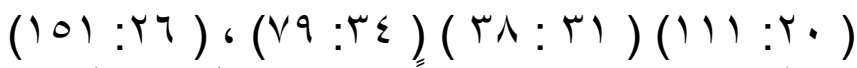

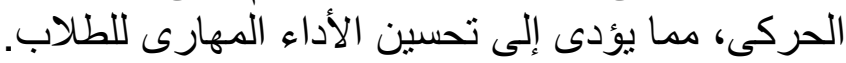

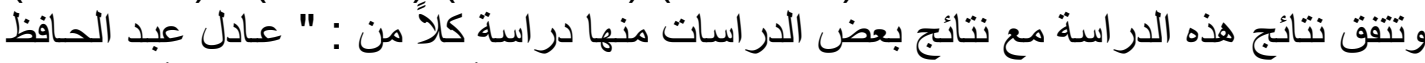

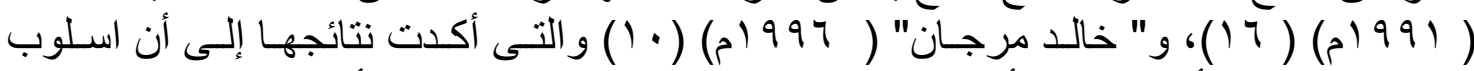

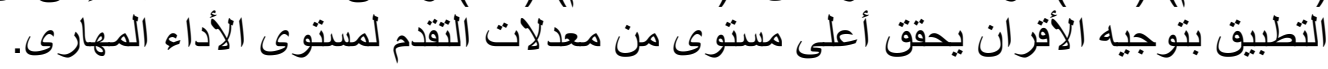
وبذلك امكن التحقق من صحة الفرض الثنانى من فروض البحت البحث.

بـ ــ مناقثة وتفسير النتائج المتعلقة بالفرض الثالث من فر وض البحث

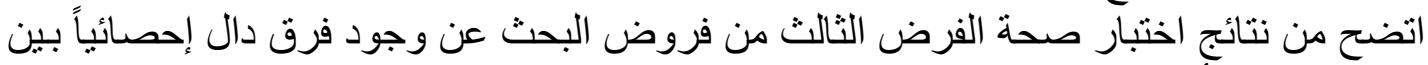

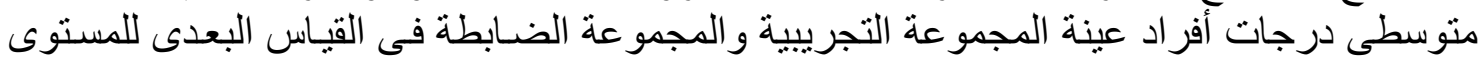

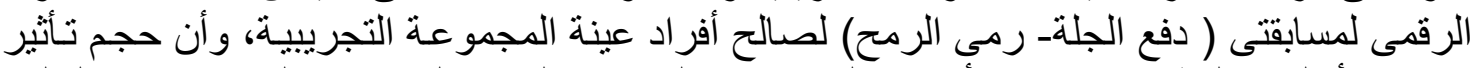

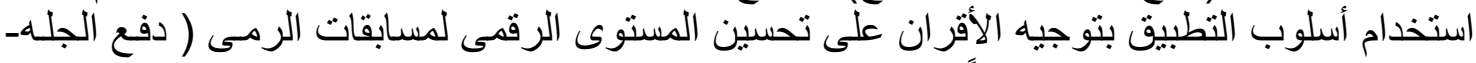
رمى الرمح) -قبد البحث- كان قوياً 


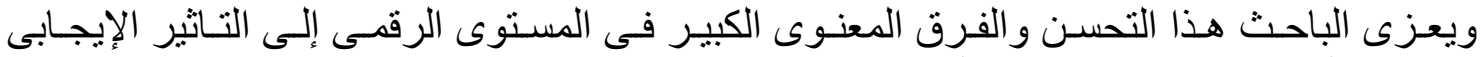

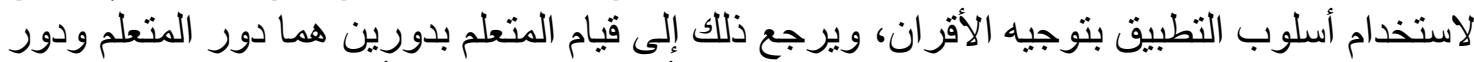

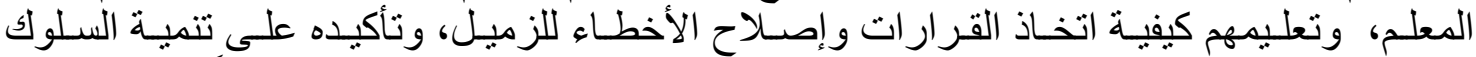

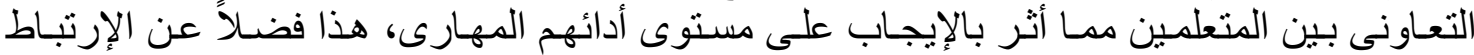

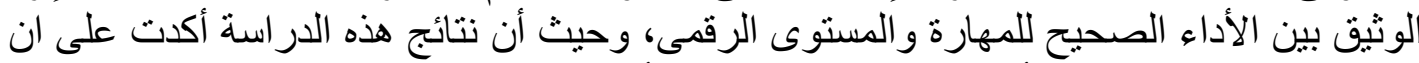

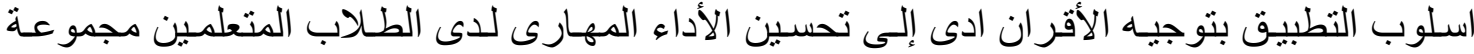

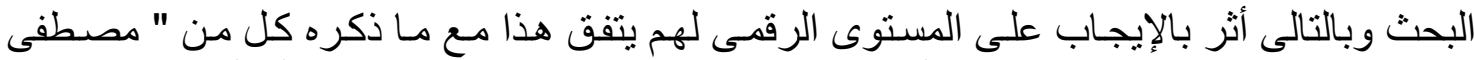

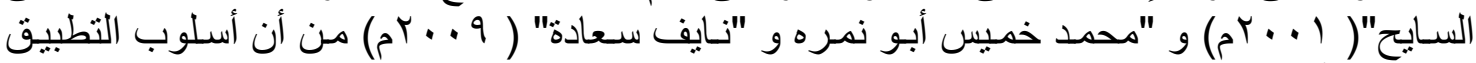

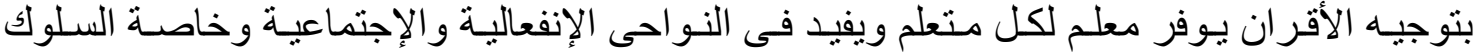
$(101: Y \tau)(\Sigma T: r \cdot)$

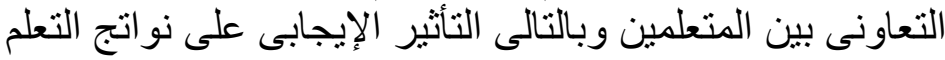

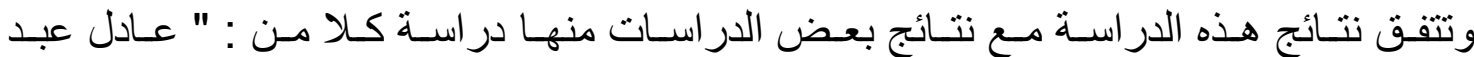

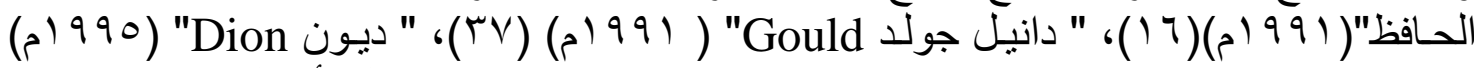

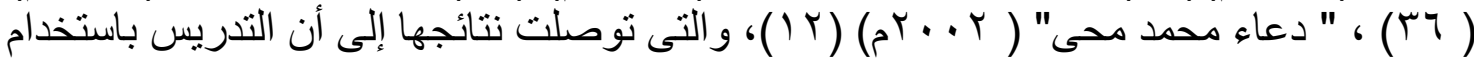

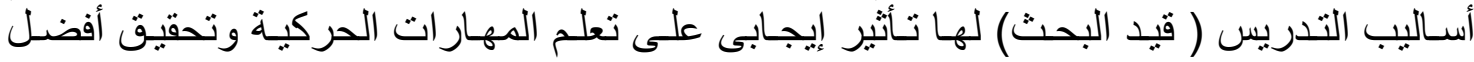
مستوى رقمى.

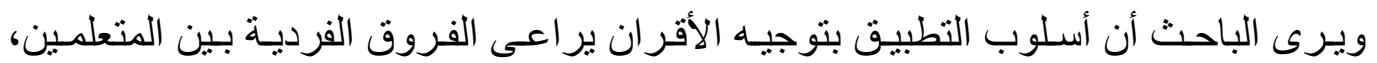

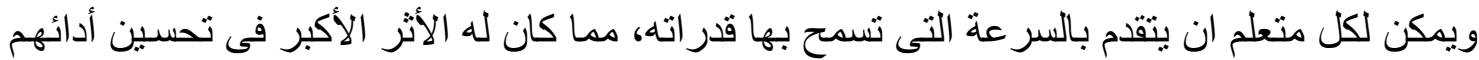

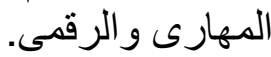
وبذلك أمكن التحقق من صحة الفرض الثالث من فروض البحث.

\section{فى ضوء ع ما أسفرت عنه نتائج الدر اسة الحالية ، يوصى الباحث بما يلى:}

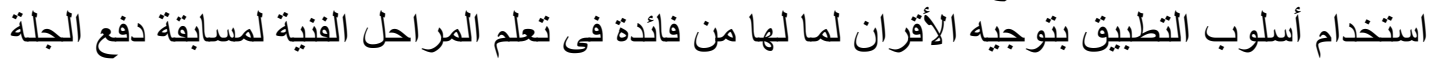

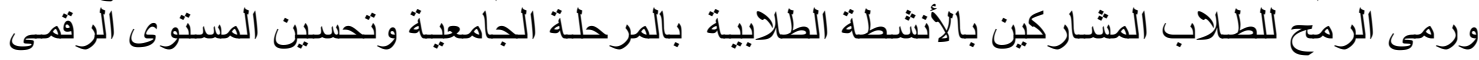

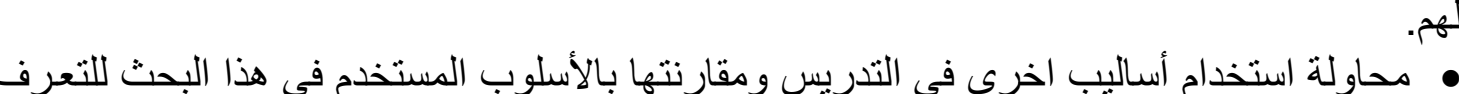

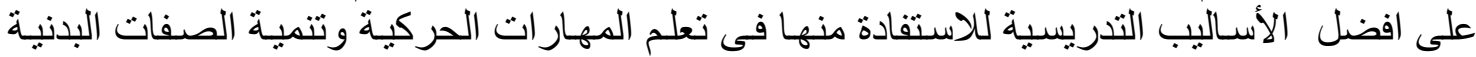
وتحسين المستوى الرقمى.

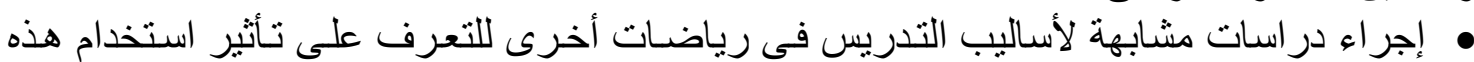
الأساليب فى تعلمهاء. • ضرورة تضمين البر امج بكليات التربية الرياضية للأسـاليب الحديثة في التدريس ومنها أسلوب

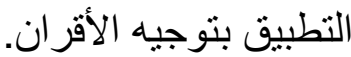

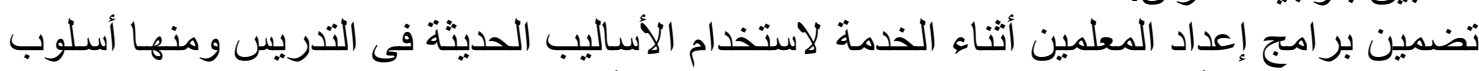
التطبيق بتوجيه الأقر ان لتعلم المهار ات الحركية وتحقيق أفضل مستوى للمتعلمين. 


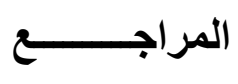

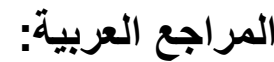

ا. إبراهيم احمد سلامة (... rم): المدخل التطبيقى للقياس فى اللياقة البنية، الإسكندرية: منشأة العارف.

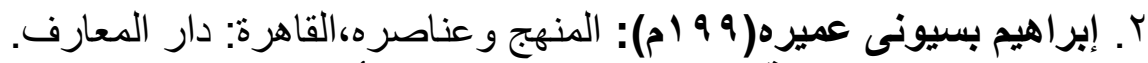

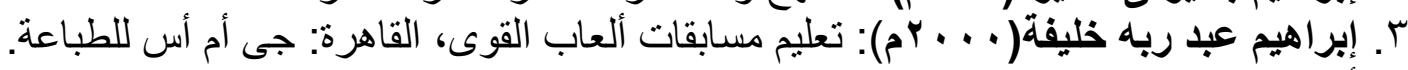

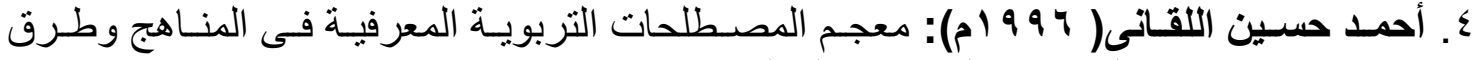

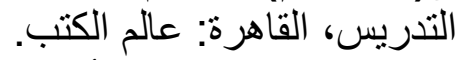

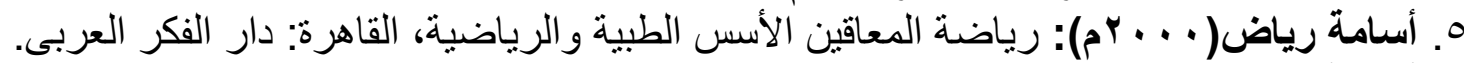

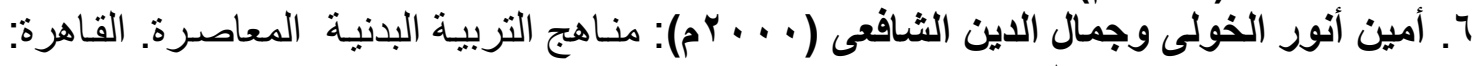
دار المعرف.

V. بسطويسى أحمد بسطويسى(9 V V ( م): مسابقات المضمار ومسابقات الميدان ( تعليم - تكنيك-

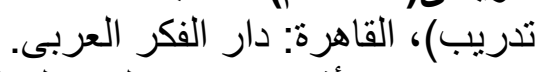

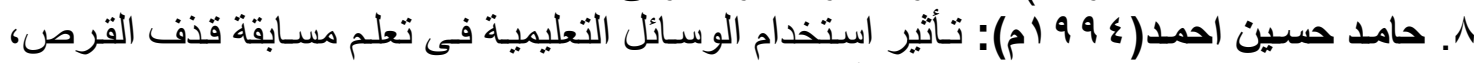

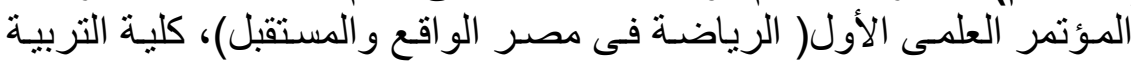

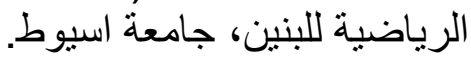

9. حسـام الدين مصطفى(9 99 (م): ألعاب القوى( المقارنة بين الأسيوياء و المعاقين، القاهرة: دار

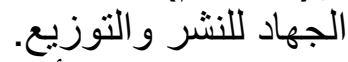

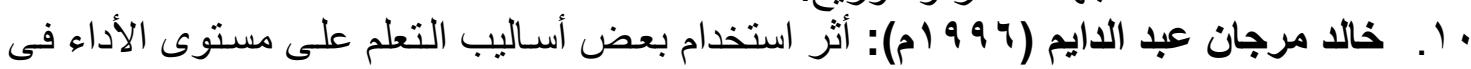

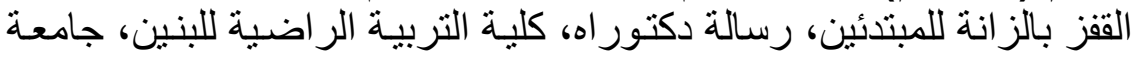

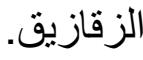

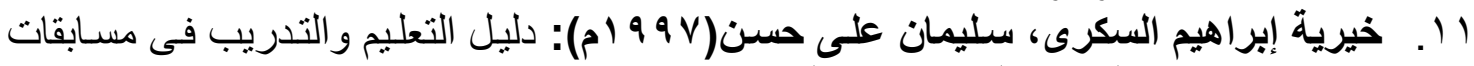

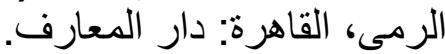

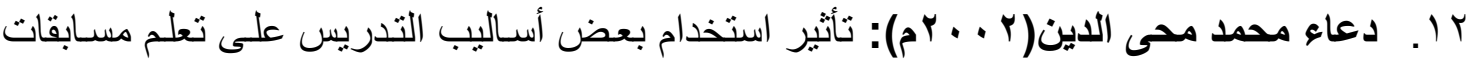

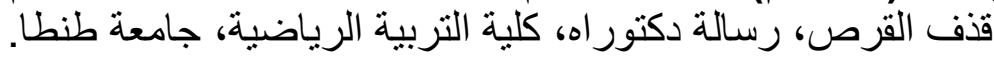

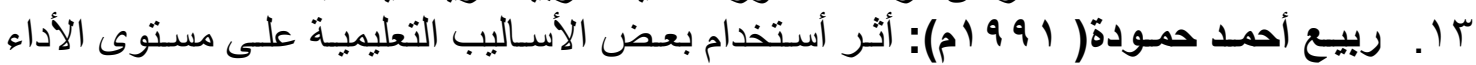

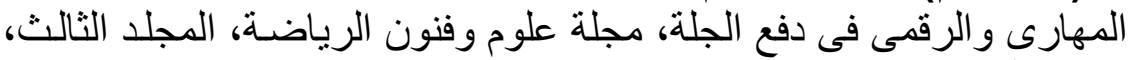

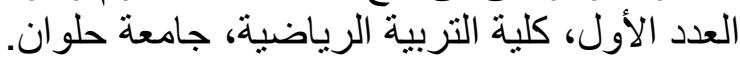

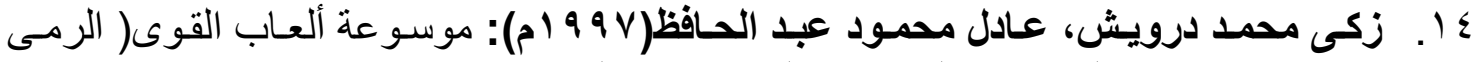

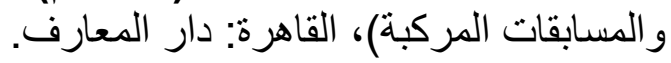

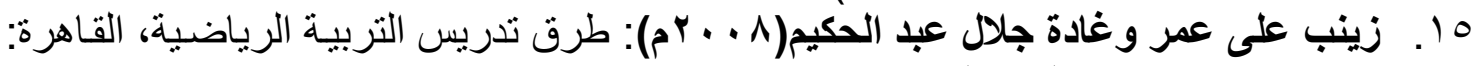

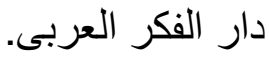

7 ا. . عادل محمد عبد الحافظ( 999 ( م): أثز استخدام أسلوب التبادل والممارسة على مستوى الأداء

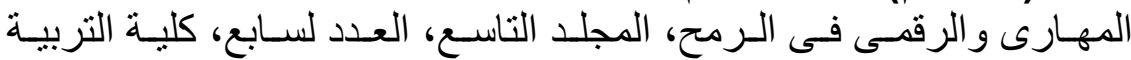
الرياضية للبنين، جامعة الزقازيق فئري 


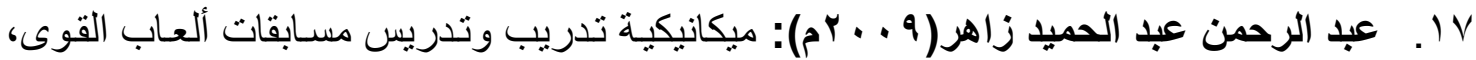
القاهرة: مركز الكتاب للنشر ماند

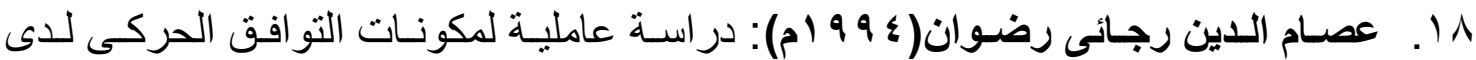

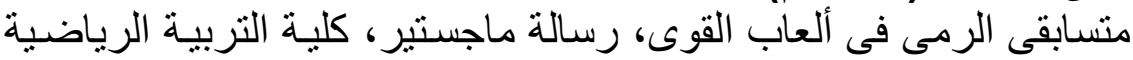

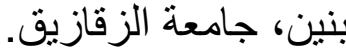

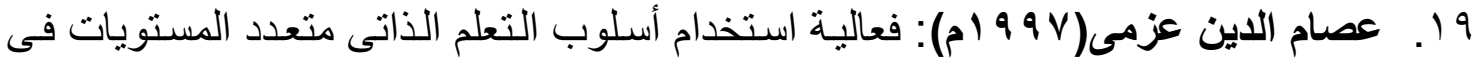

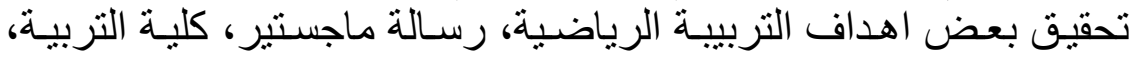

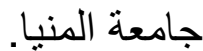

• r. عفاف عبد الكريم حسن(ع 9 9 (م): التدريس للتعلم فى التربية البدنية و الرياضية، أسـاليب

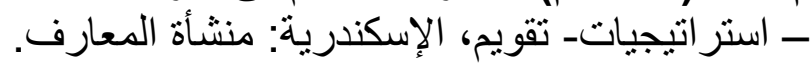

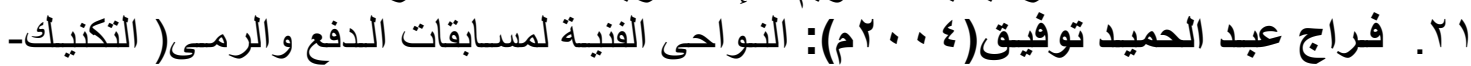

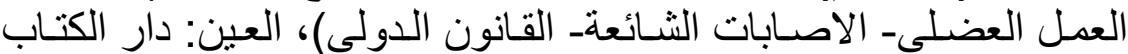

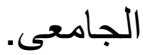

r r. فؤاد البهى السيد(9V 9 (م): علم النفس الإحصـائى وقياس العقل البشرى،طه، القاهرة: دار الفكر العربى.

بr. فيصل الملا عبد الله(1 + . rم): الاتجاه الحديث في أساليب تدريس التربية الرياضية، مجلة

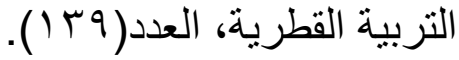

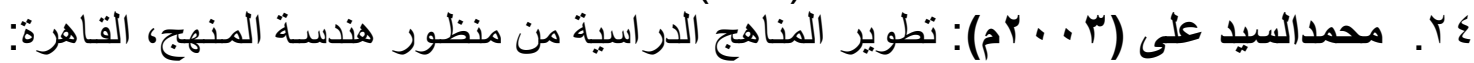

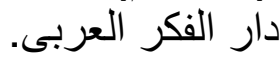

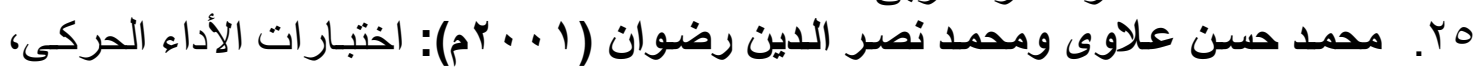

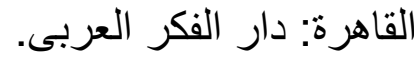

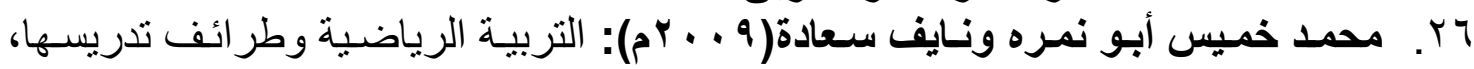
القاهرة: الثركة العربية المتحدة.

rV

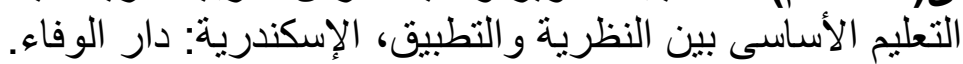

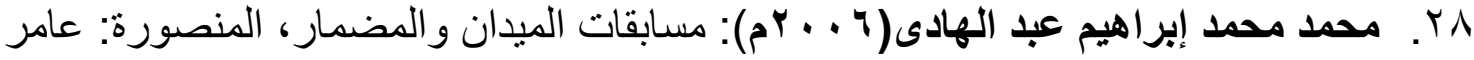
للطباعة و النشر.

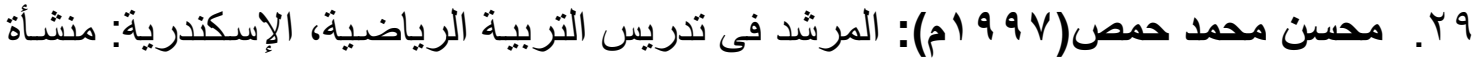
المعارف.

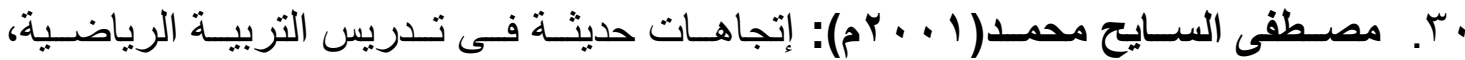

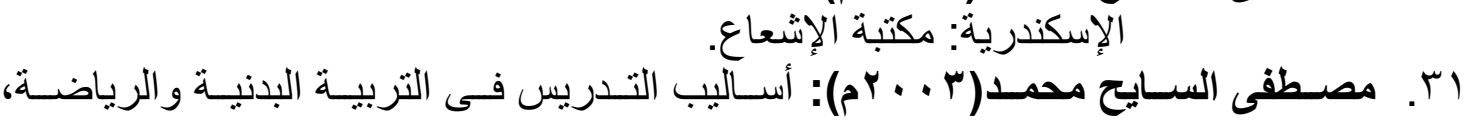

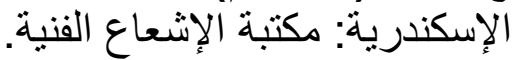

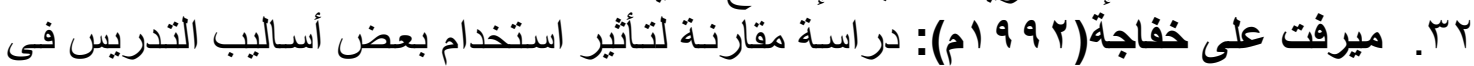

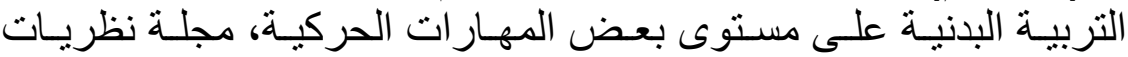

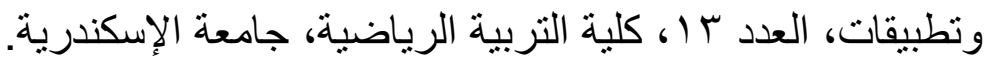

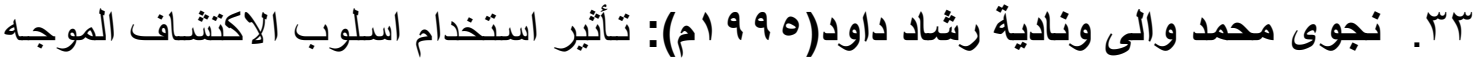

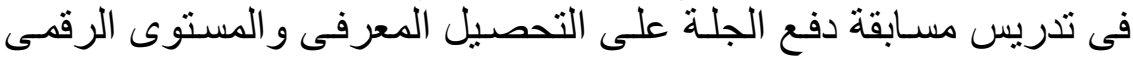

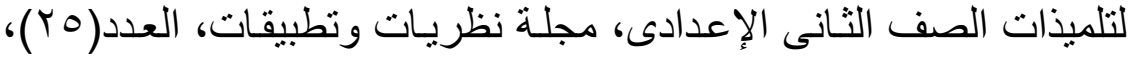
كلية التربية الرياضيةبأبى قير ، الإسكندرية. 


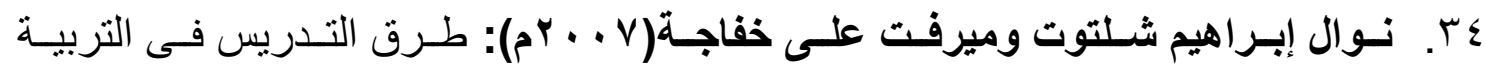

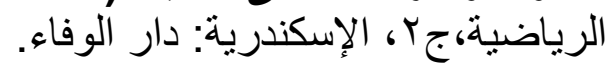

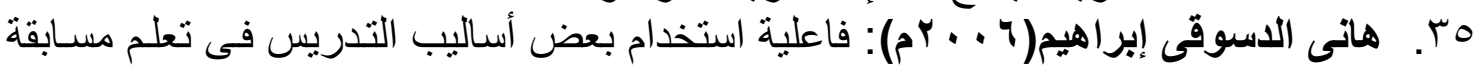

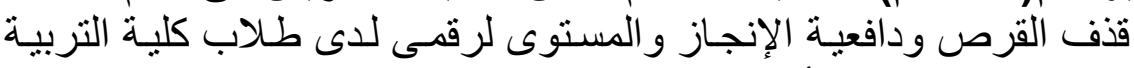

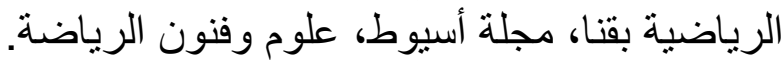

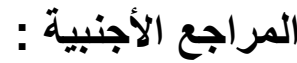

36. Dion.K.K(1995): Socialization in Adulthood,in Glindzey and Aronson (EDS) Hand Book of Social", pasycholog. Vol.11. N.Y. Randon house, 3td

37. Goould.d (1991): "Participation Motivation Competitive youth swimmers michgan State University".

38. Mosston,M\& Ashworth, S(1994): Teaching Education. Bell\& Howell Compang: Columbus.

39. Osthuizen. M.J, Griesel J.,(1992): The Effect of the Command Reciprocal and gnclusion Teaching styles on the realistion of objective in physical Education For height School Boys", S.A.Journal for Research in sport, physical Education and Recreation, Versed burg. P.24-32.

40. Rink,K.(1998): Teaching physical Education For Learning Boston, MA: Megraw.Hill.

41. Schilling. Marry Lou, E (2000): The Effects of Three Style of Teaching on University Students Sport.

42. Sidentop, D.(1991): Developing Teaching Skills in physical Education.( 3rd ed.) palo Al to, May Field. 